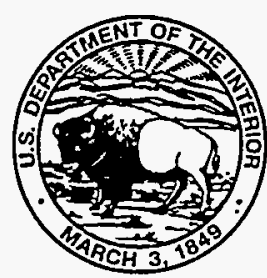

\title{
Stratigraphic Data for Wells at and near the Idaho National Engineering Laboratory, Idaho
}

U.S. Geological Survey

Open-File Report 96-248

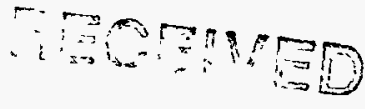

Aln $2 \div \cdots$

QSST

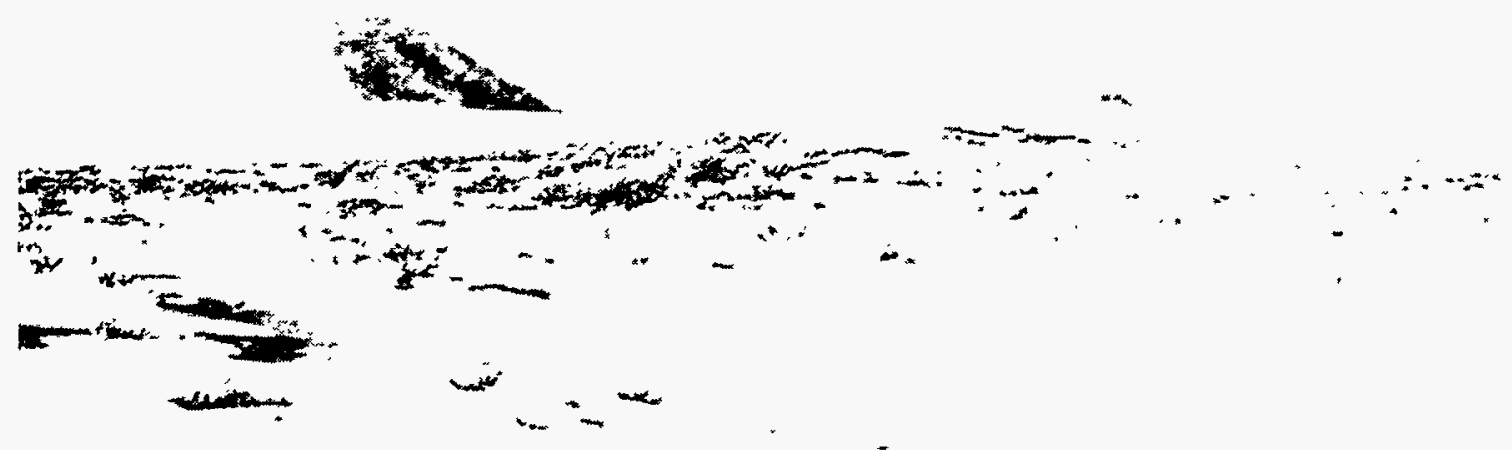

Prepared in cooperation with the

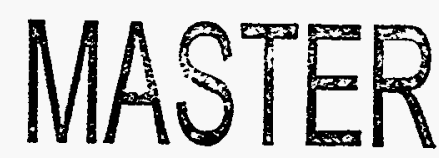

U.S. Department of Energy 
Cover: From left, East Butte, Middle Butte, and Big Southern Butte, Idaho National Engineering Laboratory

Photograph courtesy of T.D. Reynolds, formerly with U.S. Department of Energy, Environmental Sciences Branch 


\section{Stratigraphic Data for Wells at and near the Idaho National Engineering Laboratory, Idaho}

by S.R. Anderson, Daniel J. Ackerman, and

Michael J. Liszewski, U.S. Geological Survey, and R.M. Freiburger, formerly with EG\&G Idaho, Inc.

U.S. GEOLOGICAL SURVEY

Open-File Report 96-248

Prepared in cooperation with the

U.S. DEPARTMENT OF ENERGY

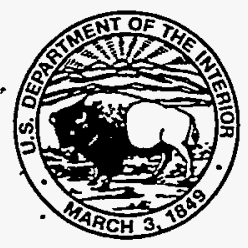

Idaho Falls, Idaho

May 1996 


\section{U.S. DEPARTMENT OF THE INTERIOR \\ BRUCE BABBITT, Secretary}

\section{U.S. GEOLOGICAL SURVEY}

GORDON P. EATON, Director

Any use of trade, product, or firm names is for descriptive purposes only and does not imply endorsement by the U.S. Government.

For additional information write to:

U.S. Geological Survey

INEL, MS 4148

P.O. Box 2230

Idaho Falls, ID 83403
Copies of this report can be purchased from:

U.S. Geological Survey

Earth Science Information Center

Open-File Reports Section

Box 25286, MS 517

Denver Federal Center

Denver, CO 80225 


\section{DISCLAIMER}

Portions of this document may be illegible in electronic image products. Images are produced from the best available original document. 


\section{DISCLAIMER}

This report was prepared as an account of work sponsored by an agency of the United States Government. Neither the United States Government nor any agency thereof, nor any of their employees, makes any warranty, express or implied, or assumes any legal liability or responsibility for the accuracy, completeness, or usefulness of any information, apparatus, product, or process disclosed, or represents that its use would not infringe privately owned rights. Reference herein to any specific commercial product, process, or service by trade name, trademark, manufacturer, or otherwise does not necessarily constitute or imply its endorsement, recommendation, or favoring by the United States Government or any agency thereof. The views and opinions of authors expressed herein do not necessarily state or reflect those of the United States Government or any agency thereof. 


\section{CONTENTS}

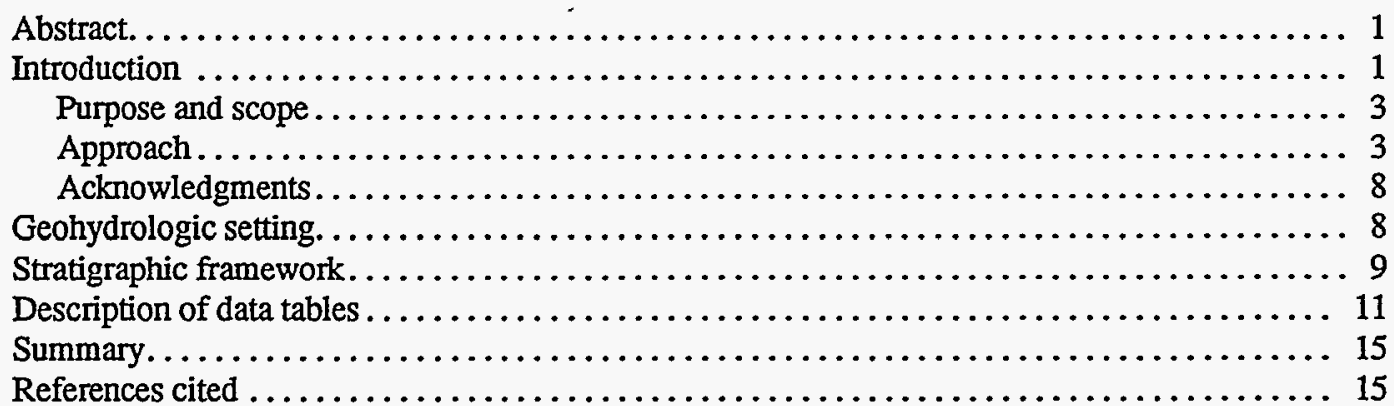

FIGURES

\section{1-5. Maps showing}

1. Location of the Idaho National Engineering Laboratory and selected facilities....... 2

2. Locations of wells at and near the Idaho National Engineering Laboratory

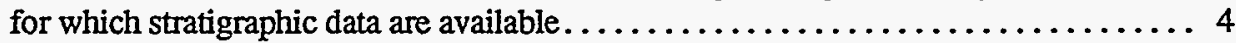

3. Locations of wells at and near the Idaho Chemical Processing Plant, Test Reactor

Area, and Central Facilities Area for which stratigraphic data are available ......... 5

4. Locations of wells at and near the Radioactive Waste Management Complex for which stratigraphic data are available $\ldots \ldots \ldots \ldots \ldots \ldots \ldots \ldots \ldots \ldots .6$

5. Locations of wells at and near the Contained Test Facility and Test Area North for which stratigraphic data are available. ..................... 7

6. Example from table 6 showing well-site and stratigraphic information for well USGS $23 \ldots \ldots 12$

7. Example of data records from tables 7 and 8 showing well-site and stratigraphic

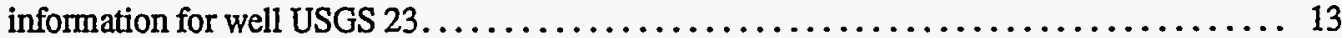

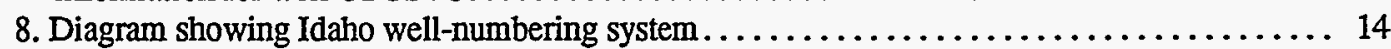

\section{TABLES}

1. Wells at and near the Idaho National Engineering Laboratory for which stratigraphic

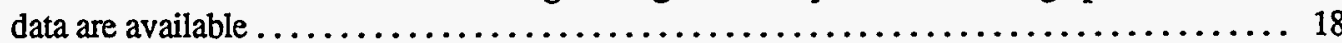

2. Selected cores and sources of data used to evaluate stratigraphic units underlying the Idaho National Engineering Laboratory and adjacent areas........................ 22

3. Wells that penetrate the effective base of the Snake River Plain aquifer at the Idaho National

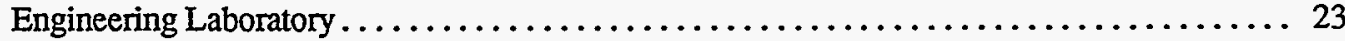

4. Stratigraphic units underlying the Idaho National Engineering Laboratory and adjacent

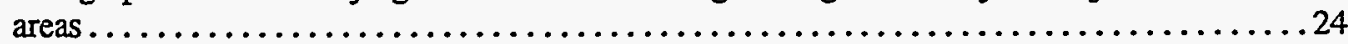

5. Measured and estimated ages of selected basait-flow groups underlying the Idaho

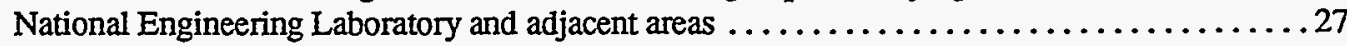

6. Well-site and stratigraphic information used for constructing a stratigraphic data base of deposits underlying the Idaho National Engineering Laboratory and adjacent areas ...... diskette

7. Well-site information suitable for constructing a stratigraphic data base of deposits underlying the Idaho National Engineering Laboratory and adjacent areas ........... diskette

8. Stratigraphic information suitable for constructing a stratigraphic data base of deposits underlying the Idaho National Engineering Laboratory and adjacent areas ........... diskette 


\section{CONVERSION FACTORS AND VERTICAL DATUM}

\begin{tabular}{rll}
\hline Multiply & By & To Obtain \\
\hline inch (in) & 2.540 & centimeter \\
foot (ft) & 0.3048 & meter \\
mile (mi) & 1.609 & kilometer \\
square mile (mi2) & 2.590 & square kilometer \\
gallon & 3.785 & liter \\
\hline
\end{tabular}

Sea level: In this report, "sea level refers to the National Geodetic Vertical datum of 1929 -a geodetic datum derived from a general adjustment of the first-order level nets of the United States and Canada, formerly called Sea Level Datum of 1929. 


\title{
Stratigraphic Data for Wells at and near the Idaho National Engineering Laboratory, Idaho
}

\author{
by S.R. Anderson, Daniel J. Ackerman, and Michael J. Liszewski, U.S. Geological \\ Survey and R.M. Freiburger, formerly with EG\&G Idaho, Inc.
}

\begin{abstract}
A stratigraphic data base containing 230 stratigraphic units in 333 wells was constructed for deposits that make up the unsaturated zone and the Snake River Plain aquifer at and near the Idaho National Engineering Laboratory in eastem Idaho. Stratigraphic units, which were identified and correlated using the data from numerous outcrops, 26 continuous cores, and 328 naturalgamma logs available in December 1993, include 121 basalt-flow groups, 102 sedimentary interbeds, 6 andesite-flow groups, and 1 inyolite dome. By volume, basalt flows make up about 90 percent of the deposits underlying most of this $890 \mathrm{mi}^{2}$ area.
\end{abstract}

Several types of data were used to identify and correlate stratigraphic units. Basalt, sediment, andesite, and inyolite were identified from outcrops and cores that were selectively evaluated for paleomagnetic inclination and polarity, $\mathrm{K}-\mathrm{Ar}$ and ${ }^{40} \mathrm{Ar} /{ }^{39} \mathrm{Ar}$ ages, petrographic characteristics, and major-oxide and trace-element chemical composition. Stratigraphic units were correlated using these data and natural-gamma logs, which respond to potassium contents of less than 1 percent in basalt to more than 4 percent in inyolite. The best correlations were obtained for basalt and sediment at Test Area North, the Naval Reactors Area, the Test Reactor Area, the Idaho Chemical Processing Plant, and the Radioactive Waste Management Complex, where most cores and two thirds of the logs were obtained. Correlations range from good at the Radioactive Waste Management Complex to uncertain in the eastern half of the study area.

Copies of the stratigraphic data are contained on a 3 1/2-inch diskette included with this report. The data are presented in two styles in American Standard Code for Information Interchange
(ASCII) format. Two files, one for well-site information and one for stratigraphic information, are presented with comma delimited fields. These two files are suitable for creation of a stratigraphic data base by most software capable of importing raw data. A third file presents the well information and stratigraphic information as text in a table format, generally one page per well. The files occupy $0.03,0.26$, and 0.81 megabyte disk space respectively.

\section{INTRODUCTION}

The Idaho National Engineering Laboratory (INEL) is operated by the U.S. Department of Energy (DOE) and covers about $890 \mathrm{mi}^{2}$ of the easterm Snake River Plain in eastem Idaho (fig. 1). Facilities at the INEL are used in the development of peacetime atomic-energy applications, nuclear safety research, defense programs, and advanced energy concepts. Liquid radionuclide and chemical wastes generated at these facilities have been discharged to onsite infiltration ponds and disposal wells since 1952. Liquid-waste disposal has resulted in detectable concentrations of several waste constituents in water in the Snake River Plain aquifer underlying the INEL (Orr and Cecil, 1991).

Concem about the potential for migration of radioactive and chemical wastes in the unsaturated zone and aquifer has resulted in numerous studies of the subsurface at the INEL. In 1988, the U.S. Geological Survey (USGS) in cooperation with the DOE, began a study of the stratigraphy of volcanic and sedimentary units underlying the INEL to determine stratigraphic relations that might affect the movement of wastes. Three earlier reports, Anderson and Lewis (1989), Anderson (1991), and Anderson and Bowers (1995), describe stratigraphic relations and their 


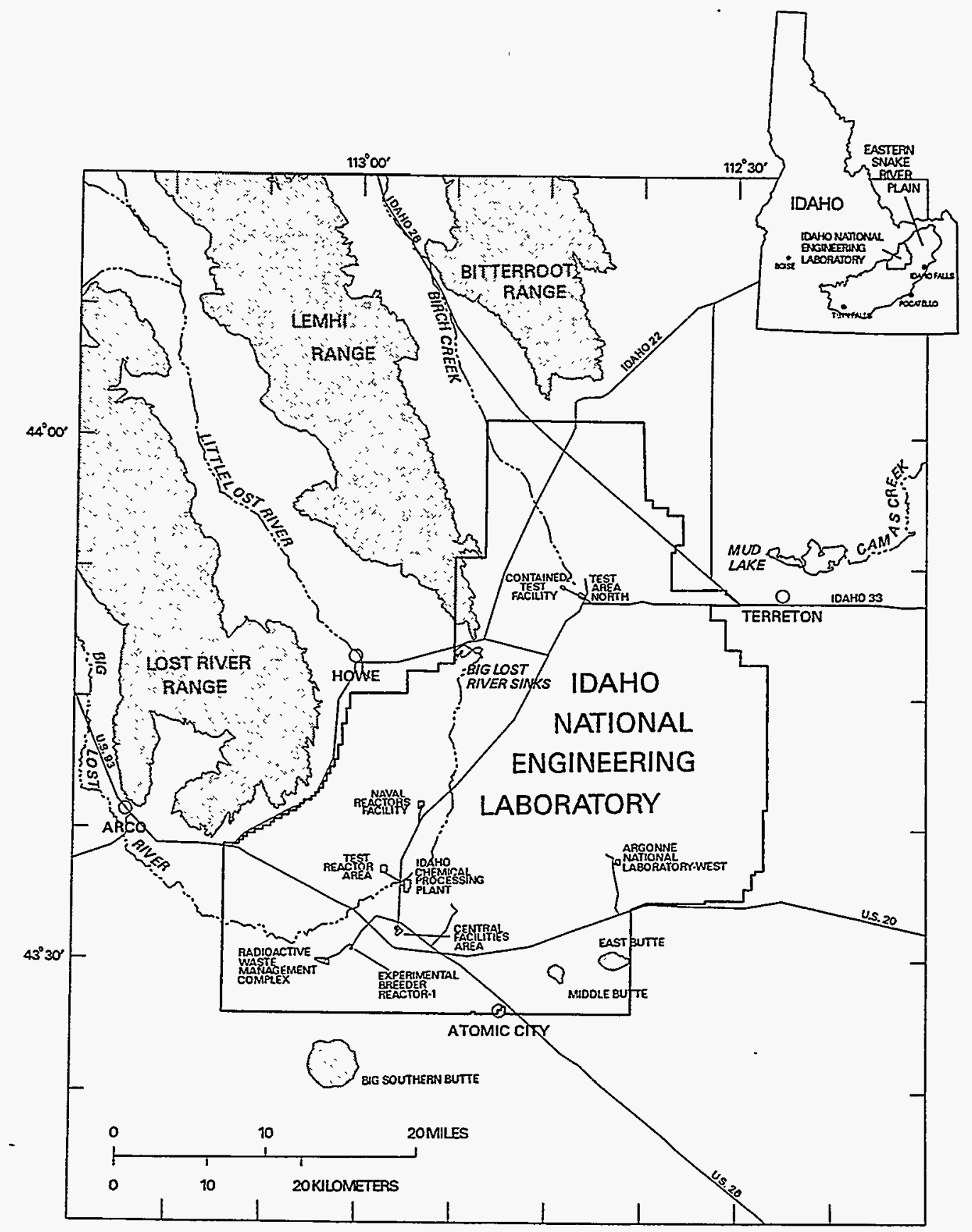

Figure 1. Location of the Idaho National Engineering Laboratory and selected facilities. 
implications regarding the movement of wastes at the Radioactive Waste Management Complex (RWMC), the Idaho Chemical Processing Plant (ICPP), the Test Reactor Area (TRA) and Test Area North (TAN) (fig. 1). Other facilities where detailed stratigraphic studies were conducted include the Contained Test Facility (CTF), Naval Reactors Facility (NRF), Argonne National Laboratory-West (ANL-W), Central Facilities Area (CFA), and Experimental Breeder Reactor-1 (EBR-1) (fig 1). Although earlier reports contain important geologic discussions, detailed stratigraphic relations and the names used to identify stratigraphic units described therein are superceded by those in this report.

In this report, a stratigraphic unit is defined as the smallest layer of a rock sequence that can be subdivided and correlated using the data available in December 1993. Stratigraphic units described in this report include 121 basalt-flow groups, 102 sedimentary interbeds, 6 andesite-flow groups, and 1 rhyolite dome. Andesite, following the general usage of Kuntz and others (1994), refers to rocks such as those of Cedar Butte that consist mainly of trachyandesite and trachydacite ( Le Bas and others, 1986; Hayden, 1992; Fishel, 1993).

\section{Purpose and Scope}

This report describes a data base containing 230 stratigraphic units in 333 wells that make up the unsaturated zone and the Snake River Plain aquifer at and near the INEL. The data base provides an intermediate-scale, computer-ready stratigraphic framework for users who need this type of geologic information. Because most wells are completed in the unsaturated zone or in the uppermost part of the aquifer, stratigraphic data for the lowermost part of the aquifer are limited. Areal coverage of the data base corresponds with that of the geologic map presented by Kuntz and others (1994), although most wells from which data were obtained are within the boundaries of the INEL. Data are concentrated near major facilities (figs. 1-5; table 1, located at end of this report), and are sparse elsewhere. The data base is constructed so that stratigraphic units can be sorted and rearranged by lithologic type for less detail or multiplied by a layering number for more detail. These features may be useful for applications such as determining the aggregate thickness of sediment and the total number of basalt-flow contacts in a model layer composed of numerous basalt-flow groups and sedimentary interbeds.

\section{Approach}

Several types of data were used to identify and correlate stratigraphic units underlying the INEL and adjacent areas. Volcanic and sedimentary units were identified from outcrops and cores selectively evaluated for paleomagnetic inclination and polarity, $\mathrm{K}-\mathrm{Ar}$ and ${ }^{40} \mathrm{Ar} /{ }^{39} \mathrm{Ar}$ ages, petrographic characteristics, and major-oxide and traceelement chemical composition. Stratigraphic units were correlated using these data and naturalgamma logs, which respond to potassium contents of less than 1 percent in basalt to more than 4 percent in myolite. The distribution and characteristics of basalt, sediment, andesite, and thyolite outcrops are described by Kuntz and others (1994). The cores and sources of data used to identify stratigraphic units underlying the area are summarized in table 2 (located at the end of this report). The method for correlating stratigraphic units using cores and natural-gamma logs is described by Anderson and Bartholomay (1996). Stratigraphic relations were determined using numerous outcrops and 26 continuous cores and 328 natural-gamma logs obtained from the wells shown in figures 2-5 and table 1. Natural-gamma logs for many of these wells are available in a report by Bartholomay (1990). These and all other logs are on file at the INEL project office of the USGS. Cores are available for inspection at the INEL Lithologic Core Storage Library.

Names, types, altitudes, depths, and thicknesses of stratigraphic units form the main body of data presented in this report. Depths of stratigraphic units, in feet below land surface, were determined visually from natural-gamma logs showing the upper and lower contacts of units after final correlations were made. Depth information, which is considered accurate to the nearest $\pm 2 \mathrm{ft}$, was transferred to data sheets and then entered into the data base. Altitude and 


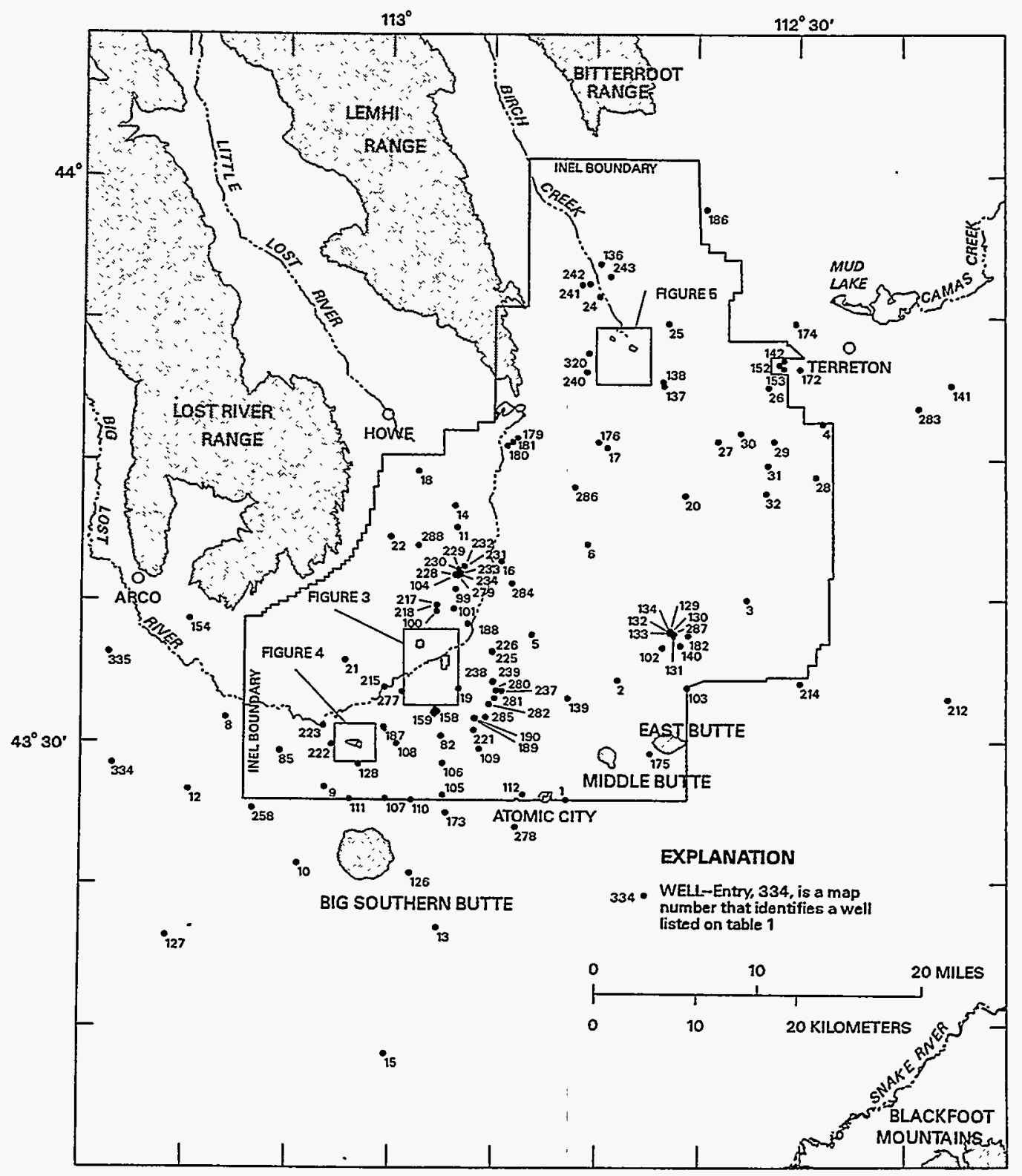

Figure 2. Locations of wells at and near the Idaho National Engineering Laboratory for which stratigraphic data are available. 


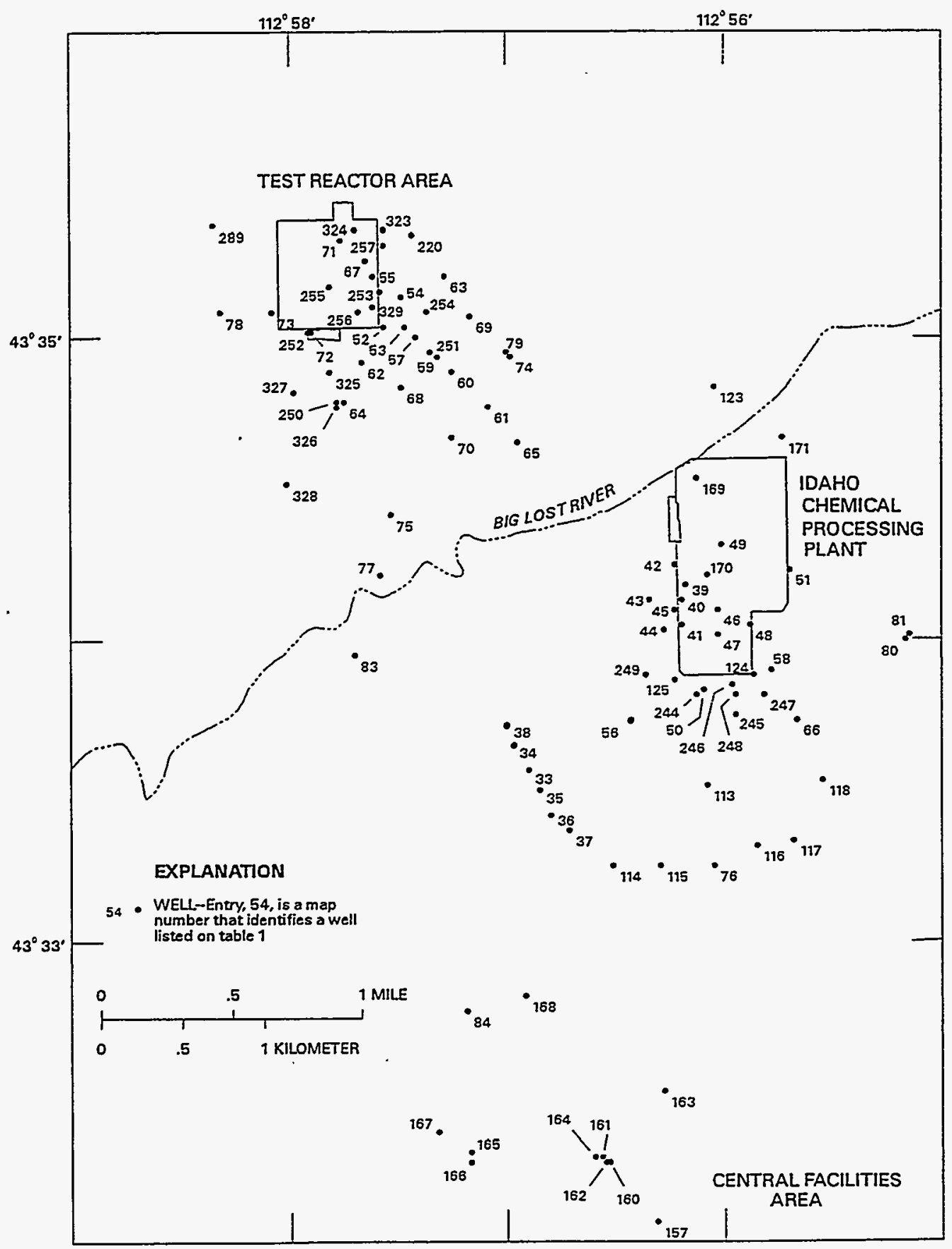

Figure 3. Locations of wells at and near the Idaho Chemical Processing Plant, Test Reactor Area, and Central Facilities Area for which stratigraphic data are available. 


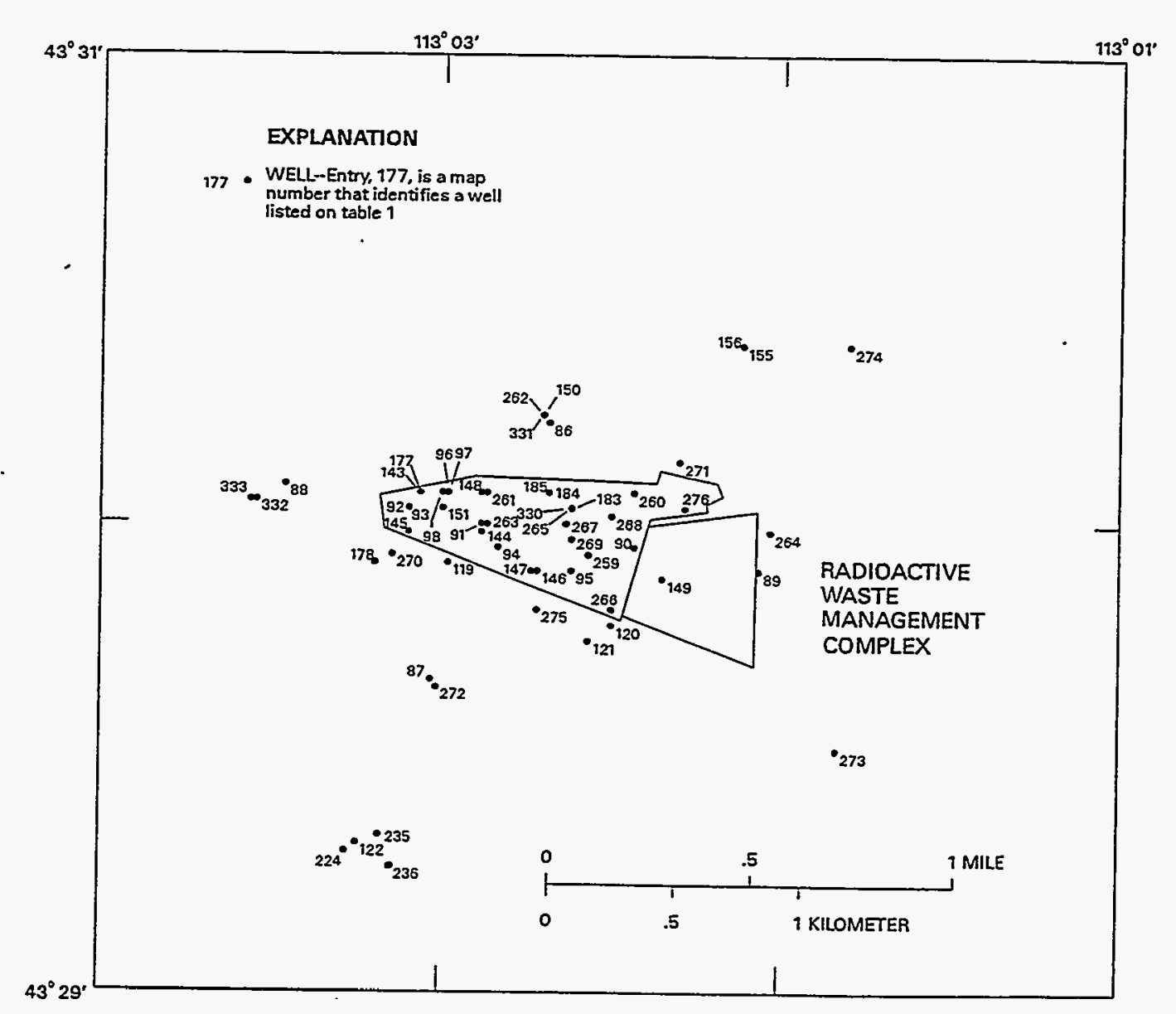

Figure 4. Locations of wells at and near the Radioactive Waste Management Complex for which stratigraphic data are available. 


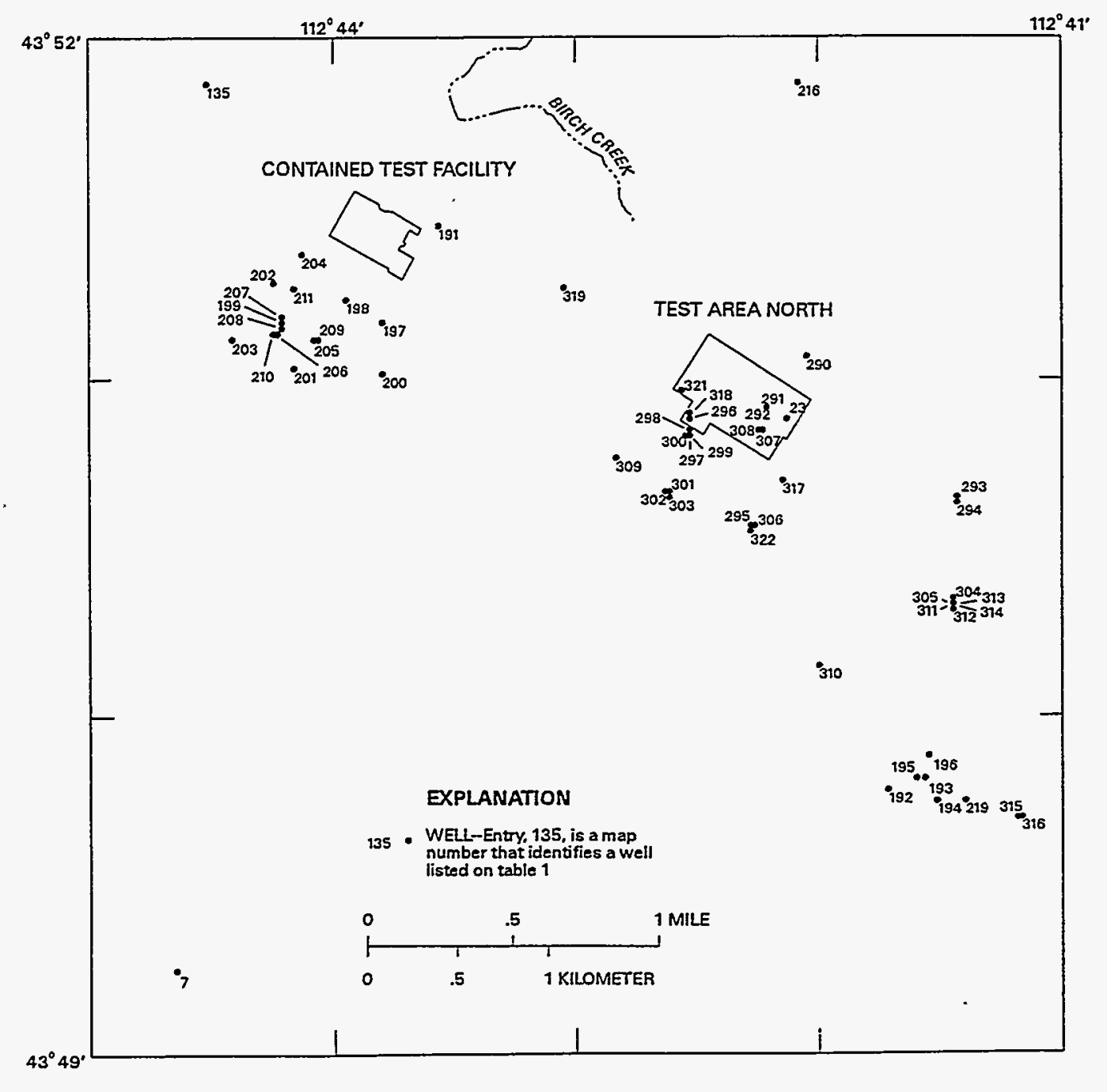

Figure 5. Locations of wells at and near the Contained Test Facility and Test Area North for which stratigraphic data are available. 
thickness of stratigraphic units were calculated using land-surface altitude and depth information. All stages of this process were manually or automatically verified to ensure that stratigraphic data were correct. The original gamma logs and data sheets showing stratigraphic interpretations and well-site information are on file with a copy of this report at the INEL project office of the USGS. Printouts of final data tables and reports and files from which well-site information was compiled also are available. Well-site information for 256 of the 333 wells in this report were compiled from Bagby and others (1984) and Bartholomay (1990). Latitude, longitude, and altitude were determined from maps and standard surveying methods and are tied to the North American Datum of 1927 and the National Geodetic Vertical Datum of 1929.

\section{Acknowledgments}

Technical assistance in preparing the stratigraphic data base was provided by Richard $P$. Smith, Lockheed Idaho Technologies Co. Funding for data entry was provided by the Department of Environmental Restoration, EG\&G Idaho, Inc. Technical assistance and data from numerous geologic investigations were obtained from Duane E. Champion, Marvin A. Lanphere, and Mel A. Kuntz, USGS, Geologic Division. Core-sampling supervision was provided by Linda C. Davis, USGS, Water-Resources Division. Numerous employees of the DOE and its INEL contractors, the State of Idaho, and the USGS provided wells, cores, logs, and technical assistance that greatly improved the quality of stratigraphic interpretations described in this report.

\section{GEOHYDROLOGIC SETTING}

The INEL is on the west-central part of the eastern Snake River Plain, a northeast-trending structural basin about $200 \mathrm{mi}$ long and 50 to $70 \mathrm{mi}$ wide (fig. 1). The INEL is underlain by a sequence of Tertiary and Quaternary volcanic rocks and sedimentary interbeds that is more than 10,000 ft thick (Doherty and others, 1979;
Whitehead, 1992; Smith and others, 1994; Hackett and others, 1994). The volcanic rocks consist mainly of basaltic lava flows, ash, and cinders in the upper part and rhyolitic ash flows and tuffs in the lower part. In places, especially along the axis of the plain, Quaternary myolite domes stand as high as $2,000 \mathrm{ft}$ above the surface of the plain. The basaltic rocks, which are interbedded with andesite and sediment, underlie the plain to depths ranging from 2,265 to $3,770 \mathrm{ft}$ in the southwestern part of the INEL. Sediment consists of fluvial, lacustrine, and eolian deposits of clay, silt, sand, and gravel. Source vents for the basalt, andesite, and thyolite are concentrated in a volcanic zone along the axis of the plain and in volcanic rift zones that trend perpendicular to the axis of the plain (Kuntz and others, 1992; Kuntz and others, 1994).

The INEL is underlain by hundreds of basalt flows, basalt-flow groups, and sedimentary interbeds; by volume, basalt makes up about 90 percent of the volume of deposits in the unsaturated zone and the aquifer in most areas. A basalt flow is a solidified body of rock that was formed by a lateral, surficial outpouring of molten lava from a vent or fissure (Bates and Jackson, 1980). A basalt-flow group consists of one or more distinct basalt flows deposited during a single eruptive event (Kuntz and others, 1980). All basalt flows of each group erupted from the same vent or vents and have similar ages, paleomagnetic properties, potassium contents, and natural-gamma emissions (Anderson and Bartholomay, 1996). The basalt flows, which locally are altered (Fromm and others, 1994), consist mainly of medium- to darkgray vesicular to dense olivine basalt. Individual flows are as much as $100 \mathrm{ft}$ thick and in places are interbedded with cinders and thin layers of sediment. Sedimentary interbeds, which are most abundant between flow groups, accumulated on the ancestral land surface for hundreds to hundreds of thousands of years during periods of volcanic quiescence. Sedimentary interbeds are as much as $50 \mathrm{ft}$ thick and consist of well to poorly sorted deposits of clay, silt, sand, and gravel. In places the interbeds contain cinders and basalt rubble. 
The basalt and sediment underlying the INEL are saturated at depth and together form the Snake River Plain aquifer. Depth to water at the INEL ranges from about $200 \mathrm{ft}$ below land surface in the northem part to about $900 \mathrm{ft}$ in the southem part (Ott and others, 1992); the general direction of ground-water flow is northeast to southwest. The effective base of the aquifer at the INEL generally coincides with the top of a thick and widespread layer of clay, silt, sand, and altered basalt that is older than about 1.6 million years (Anderson and Bowers, 1995). The top of this layer ranges in depth from 815 to $1,710 \mathrm{ft}$ below land surface in the western half of the INEL (table 3, located at the end of this report). The effective saturated thickness of the aquifer ranges from about $600 \mathrm{ft}$ near TAN to about $1,200 \mathrm{ft}$ near the ICPP and RWMC (fig. 1). Saturated thickness in the eastem half of the INEL may be greater than $1,200 \mathrm{ft}$. Hydraulic properties of the aquifer differ considerably from place to place depending on saturated thickness and the characteristics of the basalt and sediment. In places, the basalt and sediment in the uppermost part of the aquifer yield thousands of gallons per minute of water to wells, with negligible drawdown (Ackerman, 1991). Hydraulic data for the basalt, sediment, ash, and tuff underlying the aquifer are sparse, but data from well INEL-1 (fig. 2; tables 1 and 3) indicate that these deposits are relatively impermeable compared to the aquifer (Mann, 1986). Localized zones of perched ground water, which are attributed mainly to infiltration of water from unlined percolation ponds and recharge from the Big Lost River, are present in basalt and sediment overlying the regional aquifer (Cecil and others, 1991).

\section{STRATIGRAPHIC FRAMEWORK}

About 100 basalt flows, 1 andesite flow, 4 myolite domes, and surficial sediment cover the INEL and adjacent areas (Kuntz and others, 1994). Deposits identified in 333 wells completed in the unsaturated zone and the Snake River Plain aquifer include 121 basalt-flow groups, 102 sedimentary interbeds, 6 andesite-flow groups, and 1 rhyolite dome. Outcrops and subsurface deposits are subdivided into about 300 stratigraphic units, each of which is assigned an informal alpha- numeric name, from $A u(1)$ to $S 5(1)$, that corresponds to its age relative to other units. The youngest of the 232 units identified in wells is designated $\mathrm{Al}(1)$ and the oldest is designated S5(1) (table 4, located at the end of this report). Additional names, such as $\mathrm{Au}(1)$ through $\mathrm{Au}(5)$, and $\mathrm{Al}(7), \mathrm{AB}(25)$, and $\mathrm{LM} 4(3)$, are reserved for about 70 surficial units that were not identified in wells and are not listed in table 4. Stratigraphic units consist of basalt-flow groups, surficial sediment/sedimentary interbeds, andesite-flow groups, and thyolite domes. Basalt and andesite enupted from numerous vents, many of which are now buried by younger deposits (Anderson and Lewis, 1989; Anderson, 1991; Kuntz and others, 1994; Anderson and Bowers, 1995).

Stratigraphic units and names were modified from and supercede those described earlier at the RWMC (Anderson and Lewis, 1989), the ICPP and TRA (Anderson, 1991), and TAN (Anderson and Bowers, 1995). A numerical suffix was added to all names to describe the relative age of units having the same letter name (table 4). For example, the names of basalt-flow groups B, C, and $F$ at the RWMC and $L M(E), L M(W)$, and $P$ at TAN were changed to $B(1), C(1), F(1), L M 6(2)$, LM6(3), and P(1), respectively. The name of the youngest flow group, $\mathrm{A}$, at the RWMC was changed to $\mathrm{Al}(9)$ to show its age relative to the youngest unit at the INEL, Au(1). Many units, such as basalt-flow groups DE3-4(E) and DE3-4(W) at the ICPP and TRA, were subdivided and renamed on the basis of new data; these flow groups are now referred to as DE3-4(1), DE3-4(2), DE3-4(3), and DE3-4(4), respectively. The names of sedimentary interbeds, such as C-D at the RWMC and $P-Q$ at TAN, also were changed to correspond with the names used for volcanic units of the same or similar age; these interbeds are now referred to as $C D(1)$ and $P Q(1)$. Differences between this stratigraphic framework and earlier frameworks are least at TAN and greatest at the ICPP and TRA.

Ages of selected basalt, andesite, and rhyolite outcrops and cores were measured using various methods (Kuntz and others, 1994; Lanphere and others, 1994; Forman and others, 1994; Lanphere and others, 1993; Forman and others, 1993; 
Champion and others, 1988; and tables 2 and 5 , located at the end of this report). Ages of selected basalt-flow groups also were estimated using linear accumulation rates in selected wells to evaluate measured ages of flow groups with respect to their stratigraphic position in the subsurface (table 5). Ages of surficial volcanic units range from about 5.2 thousand to 1.40 million years (Kuntz and others, 1994). Measured ages of basalt-flow groups $\mathrm{Al}$ (9) through S5(1) in the unsaturated zone and Snake River Plain aquifer range from about 100 thousand to 2.56 million years (table 5). Estimated ages of flow groups $\mathrm{Al}(9)$ through S5(1) range from about 100 thousand to 1.60 million years (table 5). Agreement between measured and estimated ages is good for flow groups Al(9) through R1(1) and poor for flow groups S1(1) through S5(1) (table 5). Flow groups S1(1) through S5(1), which were identified only in the subsurface at and near TAN, either yielded unreliable measured ages (Anderson and Bowers, 1995) or are incorrectly assigned to the lowermost part of the aquifer. This conclusion is based on a unique flow group, TU(1), situated just below the effective base of the aquifer near the ICPP, that yielded a convincing ${ }^{40} \mathrm{Ar} /{ }^{39} \mathrm{Ar}$ and paleomagnetic age of about 1.86 million years (M.A. Lanphere, USGS, written commun., 1995). Determining the ages of basalt flows at the INEL is difficult because the flows are extremely young and are altered in and below the lowermost part of the aquifer. The most reliable measured ages generally are obtained from outcrops, the unsaturated zone, and the uppermost part of the aquifer (table 5).

Ages of stratigraphic units were constrained by paleomagnetic inclination and polarity data obtained from 25 cores (table 2). Stratigraphic units younger than about 780 thousand years generally have normal paleomagnetic polarity and are assigned to the Brumhes Normal-Polarity Chron (table 5). Flow group $F(1)$, a unique stratigraphic marker in the lowermost part of the unsaturated zone and uppermost part of the aquifer, has reversed polarity, an age of about 565 thousand years, and is assigned to the Big Lost ReversedPolarity Subchron (Champion and others, 1988). Units older than about 780 thousand years generally have reversed paleomagnetic polarity and are assigned to the Matuyama Reversed-Polarity Chron. Flow group TU(1), a unique stratigraphic marker just below the effective base of the aquifer, has normal polarity, an age of about 1.86 million years, and is assigned to the Olduvai Normal-Polarity Subchron (M.A. Lanphere, USGS, written commun., 1995). Paleomagnetic inclination of flow groups generally ranges from 40 to 80 degrees and is similar for all flows of each group. In well USGS 80 for example, inclination ranges from $53.9 \pm 1.9$ degrees for flow group I(1) to 76.0 \pm 2.4 degrees for flow group DE5-6(3) (Lanphere and others, 1993). In well TCH \#1, inclination ranges from $-50.2 \pm 3.9$ degrees for flow group $R 1(1)$ to $-71.5 \pm 0.6$ degrees for flow groups $\mathrm{O}(1), \mathrm{P}(1)$, and $\mathrm{Q}(1)$ (Lanphere and others, 1994).

Of the youngest 73 basalt-flow groups identified in outcrops, units $\mathrm{Au}(2)$ through $\mathrm{Au}(5), \mathrm{Al}(2)$ through $\mathrm{Al}(13)$, and $A B(2)$ through $A B(58)$, only 22 were identified in wells. This is due partly to the distribution of flow groups and partly to the distribution of wells from which cores and naturalgamma logs were obtained. Although some young flow groups were locally derived, most erupted from vents east, south, and west of the INEL (Kuntz and others, 1994) and did not have sufficient volume to cover the area now occupied by TAN, NRF, ICPP, TRA, CFA, and RWMC where most cores and two thirds of the natural-gamma logs were obtained. Identification and correlation of young flow groups in outlying areas were aided by knowing the distribution of outcrops. However, because cores and wells are sparse in these areas, identification and correlation of older flow groups are uncertain and may be biased by data collected from facilities located near the Big Lost River (fig. 1). Positive identifications and good correlations have been demonstrated for some older flow groups using cores obtained from wells up to 10 miles apart (Kuntz and others, 1980; Champion and others, 1988; Lanphere and others, 1993; Lanphere and others, 1994). However, additional cores will be needed to verify similar interpretations made from natural-gamma logs for older flow groups in outlying areas. If the number and distribution of older flow groups is similar to that of young flow groups, there may be as many as 300 additional flow groups, not yet identified, 
in the unsaturated zone and aquifer in outlying areas. Using the data obtained as of December 1993, correlations range from good at the RWMC to uncertain in the eastern half of the study area.

Although the number and distribution of flow groups in some areas are uncertain, the age and integrity of the stratigraphic framework are strengthened by the presence of many widespread sedimentary interbeds. The most widespread interbeds, $\mathrm{B}-\mathrm{BC}(2), \mathrm{CD}(1)$, DE2-3(1), DE5-6(6), DE9(1), and HI(1) (table 4), have ages of about $225,270,360,460,500$, and 630 thousand years, respectively. These and other interbeds and the surficial sediment, $\mathrm{Au}(1), \mathrm{Al}(1), \mathrm{AB}(1)$, and $\mathrm{B}(1)$, were deposited over large areas during periods of general volcanic quiescence that include the past 200 thousand years.

The distribution of basalt and sediment was controlled, in part, by subsidence and uplift as described by Anderson (1991) and Anderson and Bowers (1995). Uplift near TAN about 800 thousand years ago following the eruption of flow group LM1(1) controlled the distribution of younger basalt and sediment south and east of TAN. Similar uplifts occurred near the ICPP, TRA, and RWMC from about 580 to 350 thousand years ago and affected the distribution of basalt-flow groups DE1(1) through $H(1)$ and related sediment; uplift prevented a thick and wide-spread sequence of basalt and sediment, DE1(1) through DE8(1) (table 4), from accumulating at the RWMC. Areas of localized uplift, which are attributed to deep silicic intrusions, faulting, differential subsidence, or other processes, coincided with regional subsidence (Smith and others, 1994) and accumulation of deposits during the last 1.6 million years. These structural processes greatly affected and complicated the stratigraphic framework of the INEL and adjacent areas.

\section{DESCRIPTION OF DATA TABLES}

Stratigraphic data for 333 wells (table 1) in the unsaturated zone and the Snake River Plain aquifer are presented in two styles in tables 6,7, and 8 on a $31 / 2$-inch micro floppy disk. The data are presented as text in a table format (table 6 , diskette) and as comma delimited raw data files (tables 7 and 8, diskette).

Each page of table 6 includes well-site and stratigraphic data for a well at or near the INEL. Most wells occupy a single page; two wells, Highway \# 1 Piezo A and NPR WO-2 (table1), cover two pages. Using well USGS 23 as an example, figure 6 shows how the data are presented and explains each table entry. Entries for well USGS 23 indicate that 18 stratigraphic units, consisting of surficial sediment, 13 basaltflow groups, and 4 sedimentary interbeds, were identified in this well. Entries for Depth of hole and Depth of log indicate that the last 4 feet of flow group $F(1)$, which is not fully penetrated by the well, are estimated in well USGS 23. Entries for Site identifier and Depth of well indicate that well USGS 23 was inventoried by the USGS as of December 1993 and is used for hydrologic monitoring. Well USGS 23 is located west of the NRF in Butte County on USGS 7.5 minute topographic map Circular Butte 3 NW. Well USGS 23 , which is completed in the uppermost part of the aquifer, is typical of most wells at and near the INEL. Depth to water in the well, data that are not included in tables 6,7 , and 8 , was about $397 \mathrm{ft}$ and saturated thickness of deposits was about $70 \mathrm{ft}$ in December 1990 (Ott and others, 1992). An entry for Secondary name indicates that geophysical logs for well USGS 23 were published by Bartholomay (1990).

The comma delimited raw data files (tables 7 and 8) are provided for users who may wish to construct their own data base. Table 7 provides information for each data field for each well in the following order:
1. Primary name
2. Secondary name
3. Well location
4. Site identifier
5. Latitude
6. Longitude
7. Altitude of well
8. Depth of well
9. Depth of hole
10. Depth of log
11. County
12. Map. 
Primary name: local well identifier used by the USGS in December 1993; see table 1. Secondary name: local well identifier used by Bartholomay (1990); entry indicates that geophysical logs have been published. Well location: township, range, and section of well; see figure 8. Site identifier: unique numerical identifier of well inventoried by the USGS as of December 1993. Latitude: in degrees, minutes, and seconds. Longitude: in degrees, minutes, and seconds. Altitude of well: altitude of land surface at well, in feet above sea level. Depth of well: total depth of well used for hydrologic monitoring, in feet below land surface. Depth of hole: in feet below land surface. Depth of log: total depth of natural-gamma log, if available, in feet below land surface. County: county in which the well is located. Map: USGS 7.5 minute topographic map on which the well is located. Stratigraphic unit: the smallest layer of a rock sequence that can be subdivided and correlated using available data. Name: an informal alphanumeric name assigned to a stratigraphic unit; see table 4. Type: generalized lithologic description of a stratigraphic unit. Entries include the following types : Bas = basalt; Sed = sediment; And = andesite; and Rhy = rhyolite; see table 4. Altitude: altitude of a geologic contact, in feet above sea level. Top: altitude of the uppermost contact. Base: altitude of the lowermost contact. Depth: depth to a geologic contact, in feet below land surface. Top: depth to the uppermost contact. Base: depth to the lowermost contact. Thickness: thickness of a stratigraphic unit, in feet. Layers: estimated number of layers that make up a stratigraphic unit. Symbols: <, indicates less than. >, indicates greater than. Entries for altitude, depth, and thickness are rounded to the nearest foot and are accurate to \pm 2 feet.

\section{Example of an entry from table6.txt for well USGS 23.}

Table 6. Well site and stratigraphic information used for constructing a stratigraphic data base of deposits underlying the Idaho National Engineering Laboratory and adjacent areas--Continued

\begin{tabular}{|c|c|c|c|c|c|c|c|}
\hline & \multicolumn{3}{|c|}{ Altitude of well: $4884 \mathrm{ft}$} \\
\hline \multicolumn{5}{|c|}{ Secondary name: USGS-23 } & \multicolumn{2}{|c|}{ Depth of well: } & $463 \mathrm{ft}$ \\
\hline \multicolumn{5}{|c|}{ Well location: $04 \mathrm{~N}$ 29E 09dadI } & \multicolumn{2}{|c|}{ Depth of hole: } & 467 ft \\
\hline \multicolumn{4}{|c|}{ Site Identifier: 434055112595901} & : & \multicolumn{2}{|c|}{ Depth of log: } & $463 \mathrm{f}$ \\
\hline \multicolumn{5}{|c|}{ Latitude: $\quad 434055$} & \multicolumn{3}{|c|}{ County: } \\
\hline \multicolumn{5}{|c|}{ Longitude: 1125959} & \multicolumn{3}{|c|}{ Map: $\quad C$} \\
\hline \multicolumn{2}{|c|}{ Stratigraphic Unit } & \multicolumn{2}{|c|}{ Altitude } & \multicolumn{2}{|c|}{ Depth } & Thickness & Layer \\
\hline---- & ---- & -- & ---- & & & & \\
\hline Name & Type & Top & Base & Top & Base & & \\
\hline$\lambda$ & d & 48 & 48 & 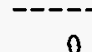 & 5 & 5 & 1 \\
\hline$A B(8)$ & Bas & 4879 & 48 & $\begin{array}{l}0 \\
5\end{array}$ & 22 & $\begin{array}{r}5 \\
17\end{array}$ & $\begin{array}{l}1 \\
1\end{array}$ \\
\hline $\mathrm{BC}(1)$ & Bas & 4862 & 4818 & 22 & 66 & 44 & $\overline{2}$ \\
\hline $\mathrm{DE} 1$ (3) & Bas & 4818 & 4805 & 66 & 79 & 13 & 1 \\
\hline DE2 (1) & Bas & 4805 & 4784 & 79 & 100 & 21 & 2 \\
\hline $\mathrm{DE} 2-3(1)$ & sed & 4784 & 4773 & 100 & 111 & 11 & 1 \\
\hline$D E 2-3(2)$ & Sed & 4773 & 4760 & 111 & 124 & 13 & 1 \\
\hline $\mathrm{DE} 3(1)$ & Bas & 4760 & 4735 & 124 & 149 & 25 & 2 \\
\hline DE4 (1) & Bas & 4735 & 4681 & 149 & 203 & 54 & 3 \\
\hline DE5 (1) & Bas & 4681 & 4621 & 203 & 263 & 60 & 3 \\
\hline $\mathrm{DE} 5-6(6)$ & Bas & 4621 & 4550 & 263 & 334 & 71 & 3 \\
\hline DE7 (1) & Bas & 4550 & 4535 & 334 & 349 & 15 & 1 \\
\hline DE8 (1) & Bas & 4535 & 4495 & 349 & 389 & 40 & 2 \\
\hline$E(1)$ & Bas & 4495 & 4466 & 389 & 418 & 29 & 2 \\
\hline$E(2)$ & Sed & 4466 & 4461 & 418 & 423 & 5 & 1 \\
\hline$E F(1)$ & Bas & 4461 & 4445 & 423 & 439 & 16 & 1 \\
\hline$E F(2)$ & Sed & 4445 & 4437 & 439 & 447 & 8 & 1 \\
\hline$F(1)$ & Bas & 4437 & $<4417$ & 447 & $>467$ & $>20$ & 1 \\
\hline
\end{tabular}

Figure 6. Example from table 6 showing well-site and stratigraphic data for USGS 23. 
Table 8 provides entries for each stratigraphic unit for each data field for each well in the following order:

1. Primary name

2. Stratigraphic unit Name

3. Stratigraphic unit Type

4. Altitude of the Top

5. Qualifier for Altitude of the Base

6. Altitude of the Base

7. Depth to the Top

8. Qualifier for Depth to the Base

9. Depth to the Base

10. Qualifier for Thickness

11. Thickness

12. Layers.

Fields which are empty have no data between delimiters. Using well USGS 23 as an example, figure 7 (below) shows how the data in tables 7 and 8 are presented.
The data files (tables 6-8) are on a highdensity, double-sided micro floppy disk with a capacity of 1.44 megabytes. The files were stored by a computer compatible with the MS-DOS operating system in American Standard Code for Information Interchange (ASCII) format. The table numbers, file names, and approximate file lengths are:

Table 6, table6.txt, 0.81 megabytes;

Table 7, table7.dat, 0.03 megabytes; and

Table 8, table8.dat, 0.26 megabytes.

Each well in the stratigraphic data base is identified by a Primary name in tables 6,7 , and 8 and can be located by a Well location or by a Latitude and Longitude listed in tables 6 and 7. The Idaho well-numbering system for a Well location listed in tables 6 and 7 is described in figure 8 .

Example of an entry from file table7.dat for well USGS 23.

USGS 23,USGS-23,04N 29E 09dcd1,434055112595901,434055,1125959,4884,463,467,463,Butte,Circular Butte 3 NW

Example of an entry from file table8.dat for well USGS 23.

USGS 23,Al(1),Sediment, $4884,4879,0,5,5,5,1$

USGS 23,AB(8),Basalt,4879,,4862,5,22,,17,1

USGS 23,BC(1),Basalt,4862,,4818,22,,66,,44,2

USGS 23,DE1(3),Basalt,4818,4805,66,,79,,13,1

USGS 23,DE2(1),Basalt,4805,4784,79,,100,21,2

USGS 23,DE2-3(1),Sediment,4784,,4773,100,,111,,11,1

USGS 23,DE2-3(2),Sediment,4773,4760,111,,124,,13,1

USGS 23,DE3(1),Basalt,4760,4735,124,,149,,25,2

USGS 23,DE4(1),Basalt,4735,4681,149,,203,,54,3

USGS 23,DE5(1),Basalt,4681,4621,203,,263,,60,3

USGS 23,DE5-6(6),Basalt,4621,,4550,263,,334,,71,3

USGS 23,DE7(1),Basalt,4550,4535,334,,349,,15,1

USGS 23,DE8(1),Basalt,4535,,4495,349,,389,,40,2

USGS 23,E(1),Basalt,4495,4466,389,,418,,29,2

USGS 23,E(2),Sediment,4466, $4461,418,, 423,2,1$

USGS 23,EF(1),Basalt,4461,4445,423,439,,16,1

USGS 23,EF(2),Sediment, $4445,4437,439,447,8,1$

USGS 23,F(1),Basalt,4437,<,4417,447,>,467,>,20,1

Figure 7. Example of data records from tables 7 and 8 showing well-site and stratigraphic information for well USGS 23. 
The U.S. Geological Survey in Idaho numbers well locations within the official rectangular subdivision of the public lands, with reference to the Boise base line and Meridian. For example, the first segment (3N) of well number 03N-29E-24dad2 designates the township north or south, the second (29E), the range east or west, and the third (24), the section in which the well is located. Letters (dad) following the section number indicate the well's location within the section and are assigned in counterclockwise order beginning with the northeast quarter. The first letter (d) denotes the 1/4 section (160-tract), the second (a) denotes the 1/4-1/4 section (40-acre tract), and the third (d) denotes the 1/4-1/4-1/4 section (10-acre tract). The last number (2) is a serial number assigned when the well was inventoried.

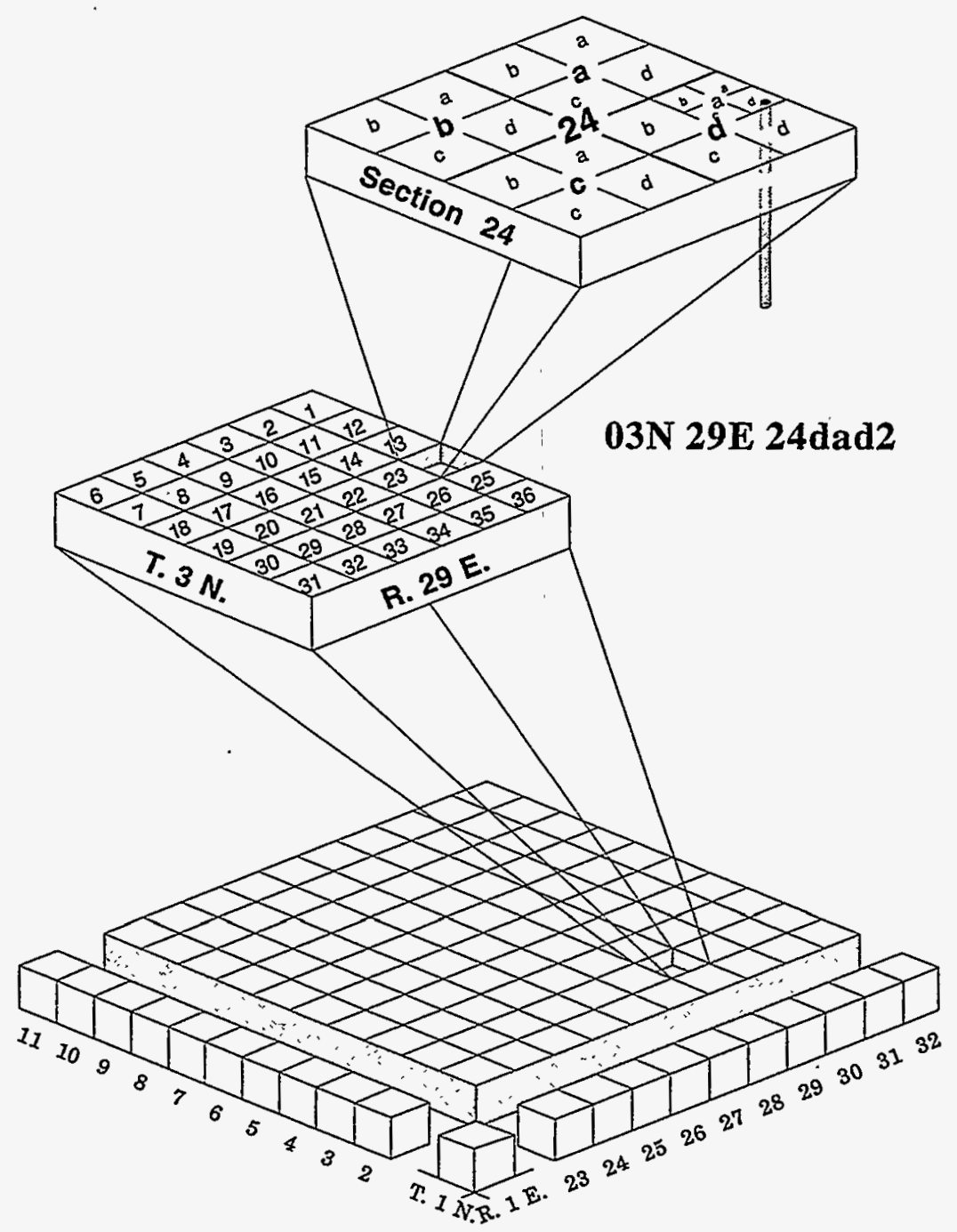

Figure 8. Idaho well-numbering system. 


\section{SUMMARY}

A stratigraphic data base containing 230 stratigraphic units in 333 wells was constructed for deposits that make up the unsaturated zone and the Snake River Plain aquifer at and near the Idaho National Engineering Laboratory. Stratigraphic units, which were identified and correlated using the data from numerous outcrops, 26 continuous cores, and 328 natural-gamma logs available in December 1993, include 121 basalt-flow groups, 102 sedimentary interbeds, 6 andesiteflow groups, and 1 rhyolite dome. By volume, basalt flows make up about 90 percent of the deposits underlying most of this $890 \mathrm{mi}^{2}$ area.

Copies of the stratigraphic data are contained on a 3 1/2-inch diskette included with this report. The data are presented in two styles in American Standard Code for Information Interchange (ASCII) format. Two files, one for well-site information and one for stratigraphic information, are presented with comma delimited fields. These two files are suitable for creation of a stratigraphic data base by most software capable of importing raw data. A third file presents the well information and stratigraphic information as text in a table format generally one page per well. The files occupy $0.03,0.26$, and 0.81 megabyte disk space respectively

\section{REFERENCES CITED}

Ackerman, D.J., 1991, Transmissivity of the Snake River Plain aquifer at the Idaho National Engineering Laboratory, Idaho: U.S. Geological Survey Water-Resources Investigations Report 91-4058 (DOE/ID-22097), 35 p.

Anderson, S.R., 1991, Stratigraphy of the unsaturated zone and uppermost part of the Snake River Plain aquifer at the Idaho Chemical Processing Plant and Test Reactors Area, Idaho National Engineering Laboratory, Idaho: U.S. Geological Survey WaterResources Investigations Report 91-4010 (DOE/ID-22095), $71 \mathrm{p}$.
Anderson, S.R., and Bartholomay, R.C., 1996, Use of natural-gamma logs and cores for determining stratigraphic relations of basalt and sediment at the Radioactive Waste Management complex, Idaho National Engineering Laboratory, Idaho: Journal of the Idaho Academy of Science, in press.

Anderson, S.R., and Bowers, Beverly, 1995, Stratigraphy of the unsaturated zone and uppermost part of the Snake River Plain aquifer at Test Area North, Idaho National Engineering Laboratory, Idaho: U.S. Geological Survey Water-Resources Investigations Report 95-4130, (DOE/ID-22122) $47 \mathrm{p}$.

Anderson, S.R. and Lewis, B.D., 1989, Stratigraphy of the unsaturated zone at the Radioactive Waste Management Complex, Idaho National Engineering Laboratory, Idaho: U.S. Geological Survey Water-Resources Investigations Report 89-4065 (DOE/ID-22080), $54 \mathrm{p}$.

Bagby, J.C., White, L.J., Barraclough, J.T., and Jensen, R.G., 1984, Ground-water site inventory data for selected wells on or near the Idaho National Engineering Laboratory, 1949 through 1982: U.S. Geological Survey OpenFile Report 84-231 (IDO-22064), 353 p.

Bartholomay, R.C., 1990, Digitized geophysical logs for selected wells on or near the Idaho National Engineering Laboratory, Idaho: U.S. Geological Survey Open-File Report 90-366 (DOE/ID-22088), $347 \mathrm{p}$.

Bates, R.L., and Jackson, J.A., eds., 1980, Glossary of geology (2d. ed.): Falls Church Va, American Geological Institute, 749 p.

Cecil, L.D., Orr, B.R., Norton, T., and Anderson, S.R., 1991, Formation of perched groundwater zones and concentrations of selected chemical constituents in water, Idaho National Engineering Laboratory, Idaho 1986-88: U.S. Geological Survey Water-Resources Investigations Report 91-4166 (DOE/ID-22100), $53 \mathrm{p}$. 
Champion, D.E., Lanphere, M.A., and Kuntz, M.A., 1988, Evidence for a new geomagnetic reversal from lava flows in Idaho-discussion of short polarity reversals in the Brunhes and Late Matuyama Polarity Chrons: Journal of Geophysical Research, v. 93, no. B10, p. 11,677-11,680.

Doherty, D.J., McBroome, L.A., and Kuntz, M.A., 1979, Preliminary geological interpretation and lithologic log of the exploratory geothermal test well (INEL-1), Idaho National Engineering Laboratory, Eastem Snake River Plain, Idaho: U.S. Geological Survey OpenFile Report 79-1248, 7 p.

Fishel, M.L., 1993, The geology of uplifted rocks on Big Southern Butte-implications for the stratigraphy and geochemistry of the Eastem Snake River Plain: Idaho State University MS Thesis, $178 \mathrm{p}$.

Forman, S.L., Pierson, J., Smith, R.P., Hackett, W.R., and Valentine, G., 1994, Assessing the accuracy of thermoluminescence for dating baked sediments beneath late Quaternary lava flows, Snake River Plain, Idaho: Joumal of Geophysical Research, v. 99, no. B8, p. 15,569-15,576.

Forman, S.L., Smith, R.P., Hackett, W.R., Tullis, J.A., and McDaniel, P.A., 1993, Timing of late Quatemary glaciations in the western United States based on the age of loess on the Eastern Snake River Plain, Idaho: Joumal of Quaternary Research, v. 40, p. 30-37.

Fromm, J.M., Hackett, W.R., and Stephens, J.D., 1994, Primary mineralogy and alteration of basalts and sediments in drillcores from the Iđaho National Engineering Laboratory, eastern Snake River Plain [Abs.]: Intemational Symposium on the Observation of the Continental Crust Through Drilling, VIIth, Santa Fe, N. Mex., April 25-30, 1994, [Abstracts] unpaginated.
Hackett, W.R., Anders, M., and Walter, R.C., 1994, Preliminary stratigraphic framework of rhyolites from corehole WO-2, Idaho National Engineering Laboratory: Caldera-related, lateTertiary silicic volcanism of the eastem Snake River Plain [abs.]: International Symposium on the Observation of the Continental Crust Through Drilling, VIIth, Santa Fe, N. Mex., April 25-30, 1994, [Abstracts] unpaginated.

Hayden, K.P., 1992, The geology and petrology of Cedar Butte, Bingham County, Idaho: Idaho State University MS Thesis, $104 \mathrm{p}$.

Knobel, L.L., Cecil, L.D., and Wood, T.R., 1995, Chemical composition of selected core samples, Idaho National Engineering Laboratory, Idaho: U.S. Geological Survey OpenFile Report 95-748, 59 p.

Kuntz, M.A., Dalrymple, G.B., Champion, D.E., and Doherty, D.J., 1980, Petrography, age, and paleomagnetism of volcanic rocks at the Radioactive Waste Management Complex, Idaho National Engineering Laboratory, Idaho, with an evaluation of potential volcanic hazards: U.S. Geological Survey Open-File Report 80-388, 63 p.

Kuntz, M.A., Covington, H.R., and Schorr, L.J., 1992, An overview of basaltic volcanism of the eastem Snake River Plain, Idaho, in Link, P.K., Kuntz, M.A., and Platt, L.B., eds., Regional geology of eastern Idaho and westem Wyoming: Geological Society of America Memoir 179, p. 227-267.

Kuntz, M.A., Skipp, Betty, Lanphere, M.A., Scott, W.E., Pierce, K.L., Dalrymple, G.B., Champion, D.E., Embree, G.F., Page, W.R., Morgan, L.A., Smith, R.P., Hackett, W.R., and Rodgers, D.W., 1994, Geologic map of the Idaho National Engineering Laboratory and adjoining areas, eastem Idaho: U.S. Geological Survey Miscellaneous Investigations Map I-2330, scale 1:100,000. 
Lanphere, M.A., Champion, D.E., and Kuntz, M.A., 1993, Petrography, age, and paleomagnetism of basalt lava flows in coreholes Well 80, NRF 89-04, NRF 89-05, and ICPP 123, Idaho National Engineering Laboratory, Idaho: U.S. Geological Survey Open-File . Report 93-327, 40 p.

Lanphere, M.A., Kuntz, M.A., and Champion, D.E., 1994, Petrography, age, and paleomagnetism of basaltic lava flows in coreholes at Test Area North (TAN), Idaho National Engineering Laboratory: U.S. Geological Survey Open-File Report 94-686, 49 p.

Lawrence, R.F., and Hackett, W.R., 1994, Petrography and lithology of Tertiary thyolites in WO-2 drillcore, Idaho National Engineering Laboratory (INEL), eastem Snake River Plain: International Symposium on the Observation of the Continental Crust through Drilling, VIIth, Santa Fe, N. Mex., April 25-30, 1994 [Abstracts] unpaginated.

Le Bas, M.J., Le Maitre, R.W., Streckeisen, A., and Zanettin, B., 1986, A chemical classification of volcanic rocks based on the total alkali-silica diagram: Joumal of Petrology, v. 27, p. $745-750$.

Mann, L.J., 1986, Hydraulic properties of rock units and chemical quality of water for INEL-1-a 10,365-foot deep test hole drilled at the Idaho National Engineering Laboratory, Idaho: U.S. Geological Survey WaterResources Investigative Report 86-4020 (IDO-22070), 23 p.

Orr, B.R., and Cecil, L.D., 1991, Hydrologic conditions and distribution of selected chemical constituents in water, Snake River Plain aquifer, Idaho National Engineering Laboratory, Idaho, 1986 to 1988: U.S. Geological Survey Water-Resources Investigations 91-4047 (DOE/ID- 22096), 56 p.

Ott, D.S., Edwards, D.D., and Bartholomay, R.C., 1992, Water-level data for selected wells on or near the Idaho National Engineering Laboratory, Idaho, 1983 through 1990: U.S. Geological Survey Open-File Report 92-643 (DOE/ID-22105), 307 p.
Reed, M.F., Bartholomay, R.C., and Hughes, S.S., 1996, Geochemistry and stratigraphic correlation of basalt lavas beneath the Idaho Chemical Processing Plant, Idaho National Engineering Laboratory, Idaho: Joumal of Environmental Geology, in press.

Shervais, John, Vetter, Scott, and Hackett, William, 1994, Chemical stratigraphy of basalts in coreholes NPR-E and WO-2, Idaho National Engineering Laboratory, Idahoimplications for plume dynamics in the Snake River Plain:International Symposium on the observation of the continental crust through drilling, VIIth, Santa Fe, N. Mex., April 2530, 1994, Proceedings, p. 93-96.

Smith, R.P., Hackett, W.R., Josten, N.E., Knutson, C.F., Jackson, S.M., Barton, C.A., Moos, D., Blackwell, D.D., and Kelley, S., 1994, Synthesis of deep drill hole information at the Idaho National Engineering Laboratory (INEL)- upper crustal environment in the continental track of a mantle hotspot: International Symposium on the observation of the continental crust through drilling, VIIth, Santa Fe, N. Mex., April 25-30, 1994, Proceedings, p. 89-92.

Whitehead, R.L., 1992, Geohydrologic framework of the Snake River Plain regional aquifer system, Idaho and eastern Oregon: U.S. Geological Survey Professional Paper 1409-B, 32 p., 6 pls. in pocket. 
Table 1. Wells at and near the Idaho National Engineering Laboratory for which stratigraphic data are available TWell: Entry, USGS 1, is a well for which stratigraphic data are available; identifier is primary name from table 6 (diskette). Figure number indicates the figure number of the map on which a well is located. Map number: Entries, 1 through 335 , indicate the map number for each well on figures $2,3,4$, or 5 and the page number for each well in table 6; numbers, 213 and 227 , are additional page numbers for welis Highway $\# 1$ Piezo A and NPR WO-2 in table 6 and are not used to identify wells on maps]

\begin{tabular}{|c|c|c|c|c|c|}
\hline Well identifier & $\begin{array}{l}\text { Figure } \\
\text { number }\end{array}$ & $\begin{array}{c}\text { Map } \\
\text { number }\end{array}$ & Well identifier & $\begin{array}{c}\text { Figure } \\
\text { number }\end{array}$ & $\begin{array}{c}\text { Map } \\
\text { number }\end{array}$ \\
\hline USGS 1 & 2 & $\overline{1}$ & USGS 43 & 3 & $\overline{42}$ \\
\hline USGS 2 & 2 & 2 & USGS 44 & 3 & 43 \\
\hline USGS 3A & 2 & 3 & USGS 45 & 3 & 44 \\
\hline USGS 4 & 2 & 4 & USGS 46 & 3 & 45 \\
\hline USGS 5 & 2 & 5 & USGS 47 & 3 & 46 \\
\hline USGS 6 & 2 & 6 & USGS 48 & 3 & 47 \\
\hline USGS 7 & 5 & 7 & USGS 49 & 3 & 48 \\
\hline USGS 8 & 2 & 8 & USGS 50 & 3 & 49 \\
\hline USGS 9 & 2 & 9 & USGS 51 & 3 & 50 \\
\hline USGS 11 & 2 & 10. & USGS 52 & 3 & 51 \\
\hline USGS 12 & 2 & 11 & USGS 53 & 3 & 52 \\
\hline USGS 13 & 2 & 12 & USGS 54 & 3 & 53 \\
\hline USGS 14 & 2 & 13 & USGS 55 & 3 & 54 \\
\hline USGS 15 & 2 & 14 & USGS 56 & 3 & 55 \\
\hline USGS 16 & 2 & 15 & USGS 57 & 3 & 56 \\
\hline USGS 17 & 2 & 16 & USGS 58 & 3 & 57 \\
\hline USGS 18 & 2 & 17 & USGS 59 & 3 & 58 \\
\hline USGS 19 & 2 & 18 & USGS 60 & 3 & 59 \\
\hline USGS 20 & 2 & 19 & USGS 61 & 3 & 60 \\
\hline USGS 21 & 2 & 20 & USGS 62 & 3 & 61 \\
\hline USGS 22 & 2 & 21 & USGS 63 & 3 & 62 \\
\hline USGS 23 & 2 & 22 & USGS 64 & 3 & 63 \\
\hline USGS 24 & 5 & 23 & USGS 65 & 3 & 64 \\
\hline USGS 25 & 2 & 24 & USGS 66 & 3 & 65 \\
\hline USGS 26 & 2 & 25 & USGS 67 & 3 & 66 \\
\hline USGS 27 & 2 & 26 & USGS 68 & 3 & 67 \\
\hline USGS 28 & 2 & 27 & USGS 69 & 3 & 68 \\
\hline USGS 29 & 2 & 28 & USGS 70 & 3 & 69 \\
\hline USGS 30A & 2 & 29 & USGS 71 & 3 & 70 \\
\hline USGS 31 & 2 & 30 & USGS 72 & 3 & 71 \\
\hline USGS 32 & 2 & 31 & USGS 73 & 3 & 72 \\
\hline USGS 33 & 2 & 32 & USGS 74 & 3 & 73 \\
\hline USGS 34 & 3 & 33 & USGS 75 & 3 & 74 \\
\hline USGS 35 & 3 & 34 & USGS 76 & 3 & 75 \\
\hline USGS 36 & 3 & 35 & USGS 77 & 3 & 76 \\
\hline USGS 37 & 3 & 36 & USGS 78 & 3 & 77 \\
\hline USGS 38 & 3 & 37 & USGS 79 & 3 & 78 \\
\hline USGS 39 & 3 & 38 & USGS 80 & 3 & 79 \\
\hline USGS 40 & 3 & 39 & USGS 81 & 3 & 80 \\
\hline USGS 41 & 3 & 40 & USGS 82 & 3 & 81 \\
\hline USGS 42 & 3 & 41 & USGS 83 & 2 & 82 \\
\hline
\end{tabular}


Table 1. Wells at or near the Idaho National Engineering Laboratory for which stratigraphic data are available-Continued

\begin{tabular}{|c|c|c|c|c|c|}
\hline Well identifier & $\begin{array}{c}\text { Figure } \\
\text { number }\end{array}$ & $\begin{array}{c}\text { Map } \\
\text { number }\end{array}$ & Well identifier & $\begin{array}{c}\text { Figure } \\
\text { number }\end{array}$ & $\begin{array}{c}\text { Map } \\
\text { number }\end{array}$ \\
\hline USGS 84 & 3 & 83 & ANL-IWP-M1 & 2 & 129 \\
\hline USGS 85 & 3 & 84 & ANL-IWP-M2 & 2 & 130 \\
\hline USGS 86 & 2 & 85 & ANL-IWP-M3 & 2 & 131 \\
\hline USGS 87 & 4 & 86 & ANL-IWP-M4 & 2 & 132 \\
\hline USGS 88 & 4 & 87 & ANL-IWP-M5 & 2 & 133 \\
\hline USGS 89 & 4 & 88 & ANL-IWP-M6 & 2 & 134 \\
\hline USGS 90 & 4 & 89 & ANP \#6 & 5 & 135 \\
\hline USGS 91 & 4 & 90 & ANP \#7 & 2 & 136 \\
\hline USGS 92 & 4 & 91 & ANP \#9 & 2 & 137 \\
\hline USGS 93 & 4 & 92 & ANP \#10 & 2 & 138 \\
\hline USGS 93A & 4 & 93 & AREA II & 2 & 139 \\
\hline USGS 94 & 4 & 94 & Arbor Test 1 & 2 & 140 \\
\hline USGS 95 & 4 & 95 & R. Archer & 2 & 141 \\
\hline USGS 96 & 4 & 96 & Ashcraft & 2 & 142 \\
\hline USGS 96A & 4 & 97 & BG-76-1 & 4 & 143 \\
\hline USGS 96B & 4 & 98 & BG-76-2 & 4 & 144 \\
\hline USGS 97 & 2 & 99 & BG-76-3 & 4 & 145 \\
\hline USGS 98 & 2 & 100 & BG-76-4 & 4 & 146 \\
\hline USGS 99 & 2 & 101 & BG-76-4A & 4 & 147 \\
\hline USGS 100 & 2 & 102 & BG-76-5 & 4 & 148 \\
\hline USGS 101 & 2 & 103 & BG-76-6 & 4 & 149 \\
\hline USGS 102 & 2 & 104 & BG-77-1 & 4 & 150 \\
\hline USGS 103 & 2 & 105 & BG-77-2 & 4 & 151 \\
\hline USGS 104 & 2 & 106 & Barney North & 2 & 152 \\
\hline USGS 105 & 2 & 107 & Bamey South & 2 & 153 \\
\hline USGS 106 & 2 & 108 & Butte City \#2 & 2 & 154 \\
\hline USGS 107 & 2 & 109 & C-1 & 4 & 155 \\
\hline USGS 108 & 2 & 110 & $\mathrm{C}-1 \mathrm{~A}$ & 4 & 156 \\
\hline USGS 109 & 2 & 111 & CFA 1 & 3 & 157 \\
\hline USGS 110 & 2 & 112 & CFA 2 & 2 & 158 \\
\hline USGS 111 & 3 & 113 & CFA 4 & 2 & 159 \\
\hline USGS 112 & 3 & 114 & CFA LF 2-8 & 3 & 160 \\
\hline USGS 113 & 3 & 115 & CFA LF 2-9 & 3 & 161 \\
\hline USGS 114 & 3 & 116 & CFA LF 2-10 & 3 & 162 \\
\hline USGS 115 & 3 & 117 & CFA LF 2-11 & 3 & 163 \\
\hline USGS 116 & 3 & 118 & CFA LF 2-12 & 3 & 164 \\
\hline USGS 117 & 4 & 119 & CFA LF 3-8 & 3 & 165 \\
\hline USGS 118 & 4 & 120 & CFA LF 3-9 & 3 & 166 \\
\hline USGS 119 & 4 & 121 & CFA LF 3-10 & 3 & 167 \\
\hline USGS 120 & 4 & 122 & CFA LF 3-11 & 3 & 168 \\
\hline USGS 121 & 3 & 123 & CPP 2 & 3 & 169 \\
\hline USGS 122 & 3 & 124 & CPP Disp. & 3 & 170 \\
\hline USGS 123 & 3 & 125 & CPP 4 & 3 & 171 \\
\hline USGS 124 & 2 & 126 & Callaway & 2 & 172 \\
\hline $1-27-14$ & 2 & 127 & Cепо Grande & 2 & 173 \\
\hline A11A31 & 2 & 128 & Cope & 2 & 174 \\
\hline
\end{tabular}


Table 1. Wells at or near the Idaho National Engineering Laboratory for which stratigraphic data are available-Continued

\begin{tabular}{|c|c|c|c|c|c|}
\hline Well identifier & $\begin{array}{c}\text { Figure } \\
\text { number }\end{array}$ & $\begin{array}{c}\text { Map } \\
\text { number }\end{array}$ & Well identifier & $\begin{array}{c}\text { Figure } \\
\text { number }\end{array}$ & $\underset{\text { number }}{\text { Map }}$ \\
\hline Corehole 1 & 2 & 175 & NA 89-1 & 2 & 222 \\
\hline Corehole 2A & 2 & 176 & NA 89-2 & 2 & 223 \\
\hline D-10 & 4 & 177 & NA 89-3 & 4 & 224 \\
\hline D-15 & 4 & 178 & NPR Test & 2 & 225 \\
\hline DH1B & 2 & 179 & NPR WO-2 & 2 & 226 \\
\hline $\mathrm{DH} 2 \mathrm{~A}$ & 2 & 180 & NRF \#4 & 2 & 228 \\
\hline $\mathrm{DH} 3$ & 2 & 181 & NRF \#6 & 2 & 229 \\
\hline DH-50 & 2 & 182 & NRF \#6P & 2 & 230 \\
\hline DO-2 & 4 & 183 & NRF \#7 & 2 & 231 \\
\hline DO-6 & 4 & 184 & NRF \#7P & 2 & 232 \\
\hline DO-6A & 4 & 185 & NRF $89-04$ & 2 & 233 \\
\hline Dahle & 2 & 186 & NRF 89-05 & 2 & 234 \\
\hline EBR I & 2 & 187 & OW-1 & 4 & 235 \\
\hline EFS Well & 2 & 188 & OW-2 & 4 & 236 \\
\hline EOCR & 2 & 189 & PBE\#2 & 2 & 237 \\
\hline EOCR (Disp) & 2 & 190 & $\operatorname{PBF}(\mathrm{CW})$ & 2 & 238 \\
\hline FET-Disp-1 & 5 & 191 & $\operatorname{PBF}(W W)$ & 2 & 239 \\
\hline GIN \#1 & 5 & 192 & PSTF Test & 2 & 240 \\
\hline GIN \#2 & 5 & 193 & P \& W \#1 & 2 & 241 \\
\hline GN \#3 & 5 & 194 & P \& W \#2 & 2 & 242 \\
\hline GIN \#4 & 5 & 195 & P \& W \#3 & 2 & 243 \\
\hline GIN \#5 & 5 & 196 & PW-1 & 3 & 244 \\
\hline GIN \#6 & 5 & 197 & PW-2 & 3 & 245 \\
\hline GIN \#7 & 5 & 198 & PW-3 & 3 & 246 \\
\hline GIN \#8 & 5 & 199 & PW-4 & 3 & 247 \\
\hline GIN \#9 & 5 & 200 & PW-5 & 3 & 248 \\
\hline GIN \#10 & 5 & 201 & PW-6 & 3 & 249 \\
\hline GIN\#11 & 5 & 202 & PW-7 & 3 & 250 \\
\hline $\mathrm{GIN} \# 12$ & 5 & 203 & PW-8 & 3 & 251 \\
\hline GIN \#13 & 5 & 204 & PW-9 & 3 & 252 \\
\hline GIN \#14 & 5 & 205 & PW-10 & 3 & 253 \\
\hline GIN \#15 & 5 & 206 & PW-11 & 3 & 254 \\
\hline GIN \#16 & 5 & 207 & PW-12 & 3 & 255 \\
\hline GIN \#17 & 5 & 208 & PW-13 & 3 & 256 \\
\hline GN \#18 & 5 & 209 & PW-14 & 3 & 257 \\
\hline GIN \#19 & 5 & 210 & Quaking Aspen Butte Well & 2 & 258 \\
\hline $\mathrm{GNN} \# 20$ & 5 & 211 & RWMC-78-1 & 4 & 259 \\
\hline Highway \#1 Piezo A & 2 & 212 & RWMC-78-2 & 4 & 260 \\
\hline Highway \#2 & 2 & 214 & RWMC-78-3 & 4 & 261 \\
\hline Highway \#3 & 2 & 215 & RWMC-78-4 & 4 & 262 \\
\hline IET Disp. & 5 & 216 & RWMC-78-5 & 4 & 263 \\
\hline INEL \#1 & 2 & 217 & RWMC-79-1 & 4 & 264 \\
\hline Water Supply for INEL \#1 & 2 & 218 & RWMC-79-2 & 4 & 265 \\
\hline LPTF Disposal & 5 & 219 & RWMC-79-3 & 4 & 266 \\
\hline MTR Test & 3 & 220 & RWMC-88-1D & 4 & 267 \\
\hline Main Gate Well & 2 & 221 & RWMC-88-02D & 4 & 268 \\
\hline
\end{tabular}


Table 1. Wells at or near the Idaho National Engineering Laboratory for which stratigraphic data are available-Continued

\begin{tabular}{|c|c|c|}
\hline Well identifier & $\begin{array}{l}\text { Figure } \\
\text { number }\end{array}$ & $\begin{array}{c}\text { Map } \\
\text { number }\end{array}$ \\
\hline$\overline{R W M C-89-01 D}$ & 4 & 269 \\
\hline RWMC M1SA & 4 & 270 \\
\hline RWMC M3S & 4 & 271 \\
\hline RWMC M4D & 4 & 272 \\
\hline RWMC M6S & 4 & 273 \\
\hline RWMC M7S & 4 & 274 \\
\hline RWMC M1OS & 4 & 275 \\
\hline RWMC Prod. & 4 & 276 \\
\hline Rifle Range Well & 2 & 277 \\
\hline Leo Roger's \#1 & 2 & 278 \\
\hline S5G Test (NRF \#5) & 2 & 279 \\
\hline Sdd-1 & 2 & 280 \\
\hline Sdd-2 & 2 & 281 \\
\hline Sdd-3 & 2 & 282 \\
\hline Siddoway & 2 & 283 \\
\hline Site 6 & 2 & 284 \\
\hline Site 9 & 2 & 285 \\
\hline Site 14 & 2 & 286 \\
\hline Site 16 & 2 & 287 \\
\hline Site 17 & 2 & 288 \\
\hline Site 19 & 3 & 289 \\
\hline TAN\#3 & 5 & 290 \\
\hline TAN \#4 & 5 & 291 \\
\hline TAN \#5 & 5 & 292 \\
\hline TAN \#6 & 5 & 293 \\
\hline TAN\#7 & 5 & 294 \\
\hline TAN \#8 & 5 & 295 \\
\hline TAN \#9 & 5 & 296 \\
\hline TAN \#10 & 5 & 297 \\
\hline TAN \#10A & 5 & 298 \\
\hline TAN \#11 & 5 & 299 \\
\hline TAN \#12 & 5 & 300 \\
\hline TAN\#13 & 5 & 301 \\
\hline TAN \#17 & 5 & 306 \\
\hline
\end{tabular}

\begin{tabular}{|c|c|c|}
\hline Well identifier & $\begin{array}{l}\text { Figure } \\
\text { number }\end{array}$ & $\begin{array}{c}\text { Map } \\
\text { number }\end{array}$ \\
\hline TAN\#13A & 5 & 302 \\
\hline TAN \#14 & 5 & 303 \\
\hline TAN \#15 & 5 & 304 \\
\hline TAN \#16 & 5 & 305 \\
\hline TAN\#18 & 5 & 307 \\
\hline TAN \#19 & 5 & 308 \\
\hline TAN \#20 & 5 & 309 \\
\hline TAN \#21 & 5 & 310 \\
\hline TAN \#22 & 5 & 311 \\
\hline TAN \#22A & 5 & 312 \\
\hline TAN \#23 & 5 & 313 \\
\hline TAN\#23A & 5 & 314 \\
\hline TAN\#24 & 5 & 315 \\
\hline TAN \#24A & 5 & 316 \\
\hline TAN Drainage Disp.\#1 & 5 & 317 \\
\hline TAN Drainage Disp.\#2 & 5 & 318 \\
\hline TAN Drainage Disp.\#3 & 5 & 319 \\
\hline TAN Exploratory Well & 2 & 320 \\
\hline TCH \#1 & 5 & 321 \\
\hline TCH \#2 Piezo A & 5 & 322 \\
\hline TRA \#3 & 3 & 323 \\
\hline TRA \#4 & 3 & 324 \\
\hline TRA 05/PZ1 & 3 & 325 \\
\hline TRA 06A & 3 & 326 \\
\hline TRA 07 & 3 & 327 \\
\hline TRA 08 & 3 & 328 \\
\hline TRA Disp. & 3 & 329 \\
\hline TW-1 & 4 & 330 \\
\hline VZT-1 & 4 & 331 \\
\hline WWW\#1 & 4 & 332 \\
\hline WWW\#2 & 4 & 333 \\
\hline Water table & 2 & 334 \\
\hline Weaver and Lowe & 2 & 335 \\
\hline
\end{tabular}


Table 2. Selected cores and sources of data used to evaluate stratigraphic units underlying the Idaho National Engineering Laboratory and adjacent areas

[Well is one from which continuous core was obtained. Depth is total depth of well and approximate total depth of core, in feet below land surface. Data include paleomagnetic inclination and polarity, $\mathrm{K}-\mathrm{Ar}$ (potassium-argon) and ${ }^{40} \mathrm{Ar} /{ }^{39} \mathrm{Ar}$ (argon-argon) ages, petrographic descriptions, and major-oxide and trace element chemistry. Symbol: -- indicates no data. Numbers in columns 3-6 indicate the following data references: $1=\mathrm{Kuntz}$ and others (1980); $2=$ Champion and others (1988); 3 = Lanphere and others (1993); 4 = Lanphere and others (1994); $5=$ Knobel and others (1995); $6=$ Reed and others (1996); 7 = Duane E. Champion, USGS, written commun., 1989-95; 8 = Marvin A. Lanphere, USGS, written commun., 1989-95; 9 = Mel A. Kuntz, USGS, written commun., 1989-95; and 10 = Roy C. Bartholomay, written commun., 1989-95. Additional data for deposits in and underlying the Snake River Plain aquifer are indicated by the following references: $11=$ Shervais and others, 1994; $12=$ Lawrence and Hackett, 1994; and $13=$ Hackett and others, 1994]

\begin{tabular}{|c|c|c|c|c|c|}
\hline $\begin{array}{l}\text { Well and core } \\
\text { identifer }\end{array}$ & $\begin{array}{l}\text { Depth } \\
\text { (feet) }\end{array}$ & $\begin{array}{c}\text { Source of } \\
\text { paleomagnetic data }\end{array}$ & $\begin{array}{c}\text { Source of } \\
\text { geochronologic } \\
\text { data }\end{array}$ & $\begin{array}{l}\text { Source of } \\
\text { petrographic data }\end{array}$ & $\begin{array}{c}\text { Source of chemical } \\
\text { data }\end{array}$ \\
\hline BG-76-1 & 228 & 1 & 1 & 1 & - \\
\hline BG-77-1 & 600 & 1 & 1,2 & 1 & 10 \\
\hline $\mathrm{C}-1 \mathrm{~A}$ & 1,805 & 7 & 8 & - & - \\
\hline Corehole 1 & 2,002 & 7 & - & - & - \\
\hline Corehole 2A & 3,000 & 7 & 8 & - & - \\
\hline DH-50 & 250 & 7 & - & - & - \\
\hline GIN \#5 & 430 & 4 & - & - & - \\
\hline GIN \#6 & 200 & 4 & - & - & -- \\
\hline NPR Test & 609 & 2 & 2 & - & 5,10 \\
\hline NPR WO-2 & 5,000 & 7,13 & 8,13 & 12 & 11 \\
\hline NRF $\# 6 \mathrm{P}$ & 500 & 7 & - & - & -- \\
\hline NRF $\# 7 P$ & 500 & 7 & 8 & - & - \\
\hline NRF 89-04 & 248 & 3 & 3 & - & -- \\
\hline NRF 89-05 & 242 & 3 & 3 & 3 & -- \\
\hline PW-13 & 148 & 7 & - & -- & -- \\
\hline $\mathrm{TCH} \# 1$ & 600 & 4 & 4 & 4 & 5 \\
\hline $\mathrm{TCH} \# 2$ Piezo A & 1,114 & 4 & 4 & 4 & 5 \\
\hline TRA 05/PZ1 & 297 & 7 & 8 & - & 5 \\
\hline USGS 80 & 204 & 3 & 3 & 3 & -- \\
\hline USGS 81 & 108 & 7 & - & - & -- \\
\hline USGS 93A & 233 & - & - & 1 & -- \\
\hline USGS 94 & 302 & 1 & 1 & 1 & -- \\
\hline USGS 118 & 570 & 7 & - & - & 10 \\
\hline USGS 121 & 746 & 7 & 8 & 9 & 6 \\
\hline USGS 123 & 744 & 3 & 3 & 3 & 6 \\
\hline WWW \#1 & 265 & 7 & - & - & -- \\
\hline
\end{tabular}


Table 3. Wells that penetrate the effective base of the Snake River Plain aquifer at and near the Idaho National Engineering Laboratory

[Depth is total depth of well, in feet below land surface. Base is the depth to the effective base of the Snake River Plain aquifer, in feet below land surface. Lithology indicates the relative abundance of basalt $(B)$ and sediment $(S)$ below the base of the aquifer to a depth of 500 feet; greatest abundance is listed first. Core indicates the availability of continuous core; see table 2]

\begin{tabular}{lcccc}
\hline Well identifier & Depth (feet) & Base (feet) & Lithology & Core \\
\hline C-1A & 1,805 & 1,710 & B, S & Yes \\
Corehole 2A & 3,000 & 846 & S, B & Yes \\
INEL \#1 & 10,365 & 965 & S, B & No \\
NPR WO-2 & 5,000 & 1,660 & B, S & Yes \\
S5G Test & 1,276 & 884 & B, S & No \\
TCH \#2 & 1,114 & 883 & B, S & Yes \\
TRA \#4 & 970 & 909 & B, S & No \\
TRA Disp & 1,275 & 907 & B, S & No \\
USGS 7 & 1,200 & 895 & B, S & No \\
USGS 15 & 1,497 & 815 & S, B & No \\
\hline
\end{tabular}


Table 4. Stratigraphic units underlying the Idaho National Engineering Laboratory and adjacent areas

[Name is informal name of stratigraphic unit modified from Anderson and Lewis (1989), Anderson (1991), and Anderson and Bowers (1995); names ranked from youngest, $\mathrm{Al}(1)$, to oldest, S5(1). Type indicates the following generalized lithologic types: Bas = basalt; Sed = sediment; And = Andesite; and Rhy = rhyolite; basalt, andesite, and rhyolite are flow groups that consist of one or more flows from a single eruptive event. Wells indicate the number of wells in which each unit is present; does not include thin sediment layers between individual basalt flows of some basalt-flow groups. See table 6 for distribution of units in wells. Additional names, such as $A u(1)$ through $A u(5)$ and $A 1(7), A B(25)$, and LM4(3), are reserved for about 70 surficial units that were not identifed in wells]

\begin{tabular}{|c|c|c|c|c|c|c|c|c|}
\hline Name & Type & Wells & Name & Type & Wells & Name & Type & Wells \\
\hline $\mathrm{Al}(1)$ & Sed & 288 & $B(1)$ & Sed & 85 & DE1(2) & Bas & 10 \\
\hline $\operatorname{Al}(3)$ & Bas & 2 & $\mathrm{~B}-\mathrm{BC}(1)$ & Bas & 6 & DE1(3) & Bas & 57 \\
\hline $\operatorname{Al}(5)$ & Bas & 2 & $B-B C(1)$ & Sed & 5 & DE1(3) & Sed & 10 \\
\hline $\operatorname{Al}(6)$ & Bas & 1 & B-BC(2) & Bas & 10 & DE1(4) & Bas & 4 \\
\hline $\operatorname{Al}(9)$ & Bas & 34 & $\mathrm{~B}-\mathrm{BC}(2)$ & Sed & 161 & DE1(4) & Sed & 2 \\
\hline $\mathrm{Al}(9)$ & Sed & 12 & $B-B C(3)$ & Bas & 32 & DE1-2(1) & Bas & 28 \\
\hline $\mathrm{AB}(1)$ & Sed & 211 & B-BC(3) & Sed & 2 & DE1-2(1) & Sed & 37 \\
\hline$A B(8)$ & Bas & 3 & B-BC(4) & Bas & 2 & DE1-2(2) & Bas & 2 \\
\hline $\mathrm{AB}(9)$ & Bas & 12 & B-BC(4) & Sed & 5 & DE1-2(2) & Sed & 11 \\
\hline$A B(10)$ & Bas & 9 & $\mathrm{BC}(1)$ & Bas & 101 & DE1-2(3) & Bas & 1 \\
\hline $\mathrm{AB}(11)$ & Bas & 8 & $\mathrm{BC}(1)$ & Sed & 27 & DEL-2(3) & Sed & 1 \\
\hline $\mathrm{AB}(11)$ & Sed & 11 & $\mathrm{BC}(2)$ & Bas & 79 & DE2(1) & Bas & 103 \\
\hline $\mathrm{AB}(12)$ & Bas & 1 & $\mathrm{BC}(2)$ & Sed & 10 & $\mathrm{DE} 2(1)$ & Sed & 42 \\
\hline$A B(13)$ & Bas & 2 & $\mathrm{BC}(3)$ & Bas & 11 & DE2-3(1) & Bas & 24 \\
\hline $\mathrm{AB}(16)$ & Bas & 1 & $\mathrm{BC}(3)$ & Sed & 42 & DE2-3(1) & Sed & 67 \\
\hline $\mathrm{AB}(17)$ & Sed & 1 & $\mathrm{BC}(4)$ & Bas & 2 & DE2-3(2) & Bas & 10 \\
\hline$A B(18)$ & Bas & 1 & $C(1)$ & Bas & 131 & DE2-3(2) & Sed & 10 \\
\hline $\mathrm{AB}(18)$ & Sed & 1 & $C(1)$ & Sed & 13 & DE2-3(3) & Bas & 1 \\
\hline$A B(22)$ & Bas & 1 & $\mathrm{CD}(1)$ & Bas & 31 & DE3(1) & Bas & 118 \\
\hline$A B(23)$ & Bas & 1 & $\mathrm{CD}(1)$ & Sed & 76 & $\mathrm{DE} 3(1)$ & Sed & 16 \\
\hline$A B(26)$ & Bas & 1 & $C D(2)$ & Bas & 4 & $\mathrm{DE} 3(2)$ & Bas & 10 \\
\hline$A B(28)$ & Bas & 1 & $\mathrm{D}(1)$ & Bas & 95 & $\mathrm{DE} 3(2)$ & Sed & 23 \\
\hline$A B(30)$ & Bas & 1 & $D(1)$ & Sed & 9 & DE3-4(1) & Bas & 42 \\
\hline $\mathrm{AB}(31)$ & Bas & 2 & $\mathrm{D}(2)$ & Bas & 2 & $\mathrm{DE} 3-4(1)$ & Sed & 4 \\
\hline$A B(47)$ & Bas & 1 & $D(2)$ & Sed & 3 & $\mathrm{DE} 3-4(2)$ & Bas & 3 \\
\hline $\mathrm{AB}(49)$ & Bas & 1 & $D(3)$ & Bas & 6 & $\mathrm{DE} 3-4(2)$ & Sed & 8 \\
\hline$A B(51)$ & Bas & 2 & $D(4)$ & Bas & 11 & DE3-4(3) & Bas & 103 \\
\hline$A B(53)$ & Bas & 1 & $\operatorname{DE} 1(1)$ & Bas & 5 & DE3-4(3) & Sed & 22 \\
\hline $\mathrm{B}(1)$ & Bas & 143 & DE1(1) & Sed & 2 & DE3-4(4) & Bas & 29 \\
\hline
\end{tabular}


Table 4. Stratigraphic units underlying the Idaho National Engineering Laboratory and adjacent areas-Continued

\begin{tabular}{|c|c|c|c|c|c|c|c|c|}
\hline Name & Type & Wells & Name & Type & Wells & Name & Type & Wells \\
\hline DE3-4(4) & Sed & 39 & $\mathrm{DE7}(2)$ & And & 1 & $\mathrm{~J}(1)$ & Sed & 3 \\
\hline DE3-4(5) & Bas & 13 & DE7-8(1) & Sed & 27 & $\mathrm{JK}(1)$ & Sed & 3 \\
\hline DE3-4(5) & Sed & 4 & DE8(1) & Bas & 123 & $K(1)$ & Bas & 18 \\
\hline DE3-4(6) & Sed & 1 & $\mathrm{DE} 8(1)$ & Sed & 4 & $\mathrm{~K}(1)$ & Sed & 6 \\
\hline $\mathrm{DEA}(1)$ & Bas & 115 & DE8(2) & And & 1 & $\mathrm{KL}(1)$ & Bas & 15 \\
\hline DEA(1) & Sed & 9 & DE9(1) & Sed & 51 & $\mathrm{KL}(1)$ & Sed & 4 \\
\hline $\mathrm{DE} 4(2)$ & And & 2 & $E(1)$ & Bas & 135 & $\mathrm{KL}(2)$ & Sed & 1 \\
\hline DEA-5(1) & Bas & 4 & $E(1)$ & Sed & 7 & $L(1)$ & Bas & 16 \\
\hline DEA-5(1) & Sed & 16 & $E(2)$ & Sed & 24 & $\mathrm{~L}(1)$ & Sed & 1 \\
\hline DE4-5(2) & Bas & 19 & $E F(1)$ & Bas & 96 & $L(2)$ & Sed & 2 \\
\hline DEA-5(2) & Sed & 1 & $E F(1)$ & Sed & 7 & LM1(1) & Bas & 3 \\
\hline DE4-5(3) & Bas & 46 & $E F(2)$ & Sed & 5 & LM1(1) & Sed & 7 \\
\hline DE4-5(3) & Sed & 36 & $\mathrm{~F}(1)$ & Bas & 98 & LM1(2) & Bas & 3 \\
\hline DEA-5(4) & Bas & 10 & $F(1)$ & Sed & 9 & LM1(2) & Sed & 7 \\
\hline DE4-5(4) & Sed & 2 & $F(2)$ & Sed & 6 & LM1(3) & Bas & 1 \\
\hline DE4-5(5) & Bas & 1 & $\mathrm{FG}(1)$ & Bas & 84 & LM1(4) & Bas & 1 \\
\hline DE4-5(5) & Sed & 2 & $F G(1)$ & Sed & 26 & LM1(4) & Sed & 2 \\
\hline DE5(1) & Bas & 122 & $F G(2)$ & Sed & 8 & LM2(1) & Bas & 6 \\
\hline DE5(1) & Sed & 9 & $G(1)$ & Bas & 98 & LM2(1) & Sed & 2 \\
\hline DE5-6(1) & And & 8 & $G(1)$ & Sed & 9 & LM2(2) & Sed & 2 \\
\hline DE5-6(1) & Sed & 1 & $G(2)$ & Sed & 3 & LM3(1) & Bas & 10 \\
\hline DE5-6(2) & Bas & 8 & $\mathrm{GH}(1)$ & Bas & 7 & $\operatorname{LM} 3(2)$ & Bas & 1 \\
\hline DE5-6(3) & Bas & 3 & $\mathrm{GH}(1)$ & Sed & 14 & $\operatorname{LM} 3(2)$ & Sed & 3 \\
\hline DE5-6(3) & Sed & 9 & $\mathrm{H}(1)$ & Bas & 51 & LM4(1) & Bas & 7 \\
\hline DE5-6(4) & Bas & 7 & $H(1)$ & Sed & 14 & LM4(1) & Sed & 1 \\
\hline DE5-6(5) & Sed & 2 & $\mathrm{HI}(1)$ & Bas & 11 & LM4(2) & Sed & 4 \\
\hline DE5-6(6) & Bas & 33 & $\mathrm{HI}(1)$ & Sed & 55 & LM4(3) & Bas & 2 \\
\hline DE5-6(6) & Sed & 71 & $\mathrm{HI}(2)$ & Sed & 1 & LM4(3) & Sed & 2 \\
\hline DE6(1) & Bas & 81 & $\mathrm{I}(1)$ & Bas & 66 & LM5(1) & Bas & 7 \\
\hline DE6(1) & Sed & 25 & $\mathrm{I}(1)$ & Sed & 3 & LM5(2) & Sed & 1 \\
\hline DE6(2) & And & 1 & $I(2)$ & Bas & 58 & LM6(1) & Bas & 3 \\
\hline DE6-7(1) & Bas & 7 & $I(2)$ & Sed & 2 & LM6(2) & Bas & 9 \\
\hline DE6-7(1) & Sed & 33 & $\mathrm{IJ}(1)$ & Bas & 2 & LM6(3) & Bas & 11 \\
\hline DE7(1) & Bas & 120 & $I(1)$ & Sed & 12 & LM6(3) & Sed & 2 \\
\hline $\operatorname{DE7}(1)$ & Sed & 6 & $\mathrm{~J}(1)$ & Bas & 34 & LM7(1) & Bas & 1 \\
\hline
\end{tabular}


Table 4. Stratigraphic units underlying the Idaho National Engineering Laboratory and adjacent areas--Continued

\begin{tabular}{|c|c|c|c|c|c|c|c|c|}
\hline Name & Type & Wells & Name & Type & Wells & Name & Type & Wells \\
\hline LM7(2) & Sed & 4 & $\mathrm{NO}(1)$ & Bas & 1 & QR(3) & And & 1 \\
\hline LM8(1) & Bas & 2 & $N O(1)$ & Sed & 8 & $\mathrm{R} 1(1)$ & Bas & 9 \\
\hline LM8(2) & Sed & 1 & $O(1)$ & Bas & 40 & $\mathrm{R} 1(2)$ & Sed & 10 \\
\hline$M(1)$ & Bas & 60 & $O(1)$ & Sed & 2 & $\mathrm{R} 2(1)$ & Bas & 11 \\
\hline $\mathrm{M}(2)$ & Sed & 15 & $\mathrm{OP}(1)$ & Sed & 10 & $\mathrm{R} 2(2)$ & Sed & 1 \\
\hline $\mathrm{M}(2)$ & Bas & 1 & $P(1)$ & Bas & 55 & $S 1(1)$ & Bas & 5 \\
\hline $\mathrm{MN}(1)$ & Bas & 64 & $\mathrm{P}(2)$ & Bas & 3 & $S 1(2)$ & Sed & 1 \\
\hline $\operatorname{MN}(2)$ & Sed & 7 & $P(3)$ & Bas & 1 & $S 2(1)$ & Bas & 5 \\
\hline$N(1)$ & Bas & 64 & $\mathrm{PQ}(1)$ & Sed & 19 & $S 2(2)$ & Sed & 4 \\
\hline$N(2)$ & Sed & 1 & $\mathrm{Q}(1)$ & Bas & 41 & S3(1) & Bas & 3 \\
\hline$N(3)$ & Bas & 1 & $Q(2)$ & Bas & 1 & $S 4(1)$ & Bas & 1 \\
\hline$N(4)$ & Bas & 2 & $\mathrm{QR}(1)$ & Sed & 14 & $S 5(1)$ & Bas & 2 \\
\hline$N(5)$ & Sed & 1 & $\mathrm{QR}(2)$ & Rhy & 1 & & & \\
\hline
\end{tabular}


Table 5. Measured and estimated ages of selected basalt-flow groups underlying the Idaho National Engineering Laboratory and adjacent areas

[Each basalt-flow group, Al(9) through TU(1), includes one or more basalt flows deposited during a single eruptive event. Measured age is analytical age determined mainly by the $\mathrm{K}-\mathrm{Ar}$ method; ages for $\mathrm{Al}(9), 101 \pm 7 \mathrm{Ka}$, and TU(1), $1.865 \pm 0.024 \mathrm{Ma}$, determined by thermoluminescence and ${ }^{40} \mathrm{Ar} /{ }^{39} \mathrm{Ar}$ methods, respectively. Estimated age is age that was determined using all measured ages and linear accumulation rates in selected wells; ages are listed in thousands (Ka) or millions (Ma) of years before present. Paleomagnetic polarity indicates normal $(N)$ or reversed $(R)$ polarity. Sample location indicates well or outcrop from which samples were obtained. Sample depth indicates depth or depth interval for age samples obtained from weils, in feet below land surface; letter, $\mathrm{S}$, indicates surface or near surface samples. Hydrologic unit indicates that sample was obtained from: $1=$ the unsaturated zone, $2 \mathrm{U}=$ the uppermost 300 feet of the Snake River Plain aquifer, $2 \mathrm{~L}$ = the lowermost part of the aquifer; or 3 $=$ below the effective base of the aquifer. Large differences between measured and estimated ages, such as for flow groups S1(1), S2(1), and S5(1) at TAN, indicate areas that need additional study. See table 2 for data references]

\begin{tabular}{|c|c|c|c|c|c|c|}
\hline $\begin{array}{l}\text { Basalt-flow } \\
\text { group }\end{array}$ & Measured age & Estimated age & $\begin{array}{l}\text { Paleomagnetic } \\
\text { polarity }\end{array}$ & Sample location & $\begin{array}{l}\text { Sample } \\
\text { depth }\end{array}$ & $\begin{array}{l}\text { Hydrologic } \\
\text { unit }\end{array}$ \\
\hline \multirow[t]{2}{*}{$\mathrm{Al}(9)$} & $95 \pm 50 \mathrm{Ka}$ & $100 \mathrm{Ka}$ & $N$ & BG-77-1 & 30 & 1 \\
\hline & $10 \mathrm{I} \pm 7 \mathrm{Ka}$ & & $N$ & RWMC & $S$ & 1 \\
\hline $\mathrm{B}(1)$ & $<200 \mathrm{Ka}$ & $200 \mathrm{Ka}$ & $\mathbf{N}$ & BG-77-1 & 81 & 1 \\
\hline $\mathrm{BC}(1)$ & $247 \pm 46 \mathrm{Ka}$ & $240 \mathrm{Ka}$ & $\mathrm{N}$ & NPR Test & 81 & 1 \\
\hline $\mathrm{DE} 1(2)$ & $303 \pm 30 \mathrm{Ka}$ & $300 \mathrm{Ka}$ & $\mathrm{N}$ & NRF 89-05 & 79 & 1 \\
\hline $\mathrm{DE} 2(1)$ & $350 \pm 40 \mathrm{Ka}$ & $350 \mathrm{Ka}$ & $N$ & NPR Test & 157 & 1 \\
\hline DE5(1) & $441 \pm 77 \mathrm{Ka}$ & $440 \mathrm{Ka}$ & $\mathbf{N}$ & NPR Test & 352 & 1 \\
\hline DE8(1) & - $491 \pm 80 \mathrm{Ka}$ & $490 \mathrm{Ka}$ & $\mathrm{N}$ & NPR Test & 444 & 1 \\
\hline$E(1)$ & $515 \pm 85 \mathrm{Ka}$ & $515 \mathrm{Ka}$ & $\mathrm{N}$ & BG-77-1 & 300 to 329 & 1 \\
\hline$F(1)$ & $565 \pm 14 \mathrm{Ka}$ & $565 \mathrm{Ka}$ & $\mathbf{R}$ & BG-77-1 & 426 to 544 & 1 \\
\hline$F G(1)$ & $580 \pm 93 \mathrm{Ka}$ & $580 \mathrm{Ka}$ & $\mathbf{N}$ & NPR Test & 508 & $2 \mathrm{U}$ \\
\hline $\mathrm{H}(1)$ & $619 \pm 22 \mathrm{Ka}$ & $620 \mathrm{Ka}$ & $\mathbf{N}$ & USGS 123 & 540 & $2 \mathrm{U}$ \\
\hline$I(1)$ & $641 \pm 54 \mathrm{Ka}$ & $640 \mathrm{Ka}$ & $\mathrm{N}$ & NPR Test & 606 & $2 \mathrm{U}$ \\
\hline $\operatorname{LM1}(2)$ & $807 \pm 55 \mathrm{Ka}$ & $805 \mathrm{Ka}$ & $\mathbf{R}$ & Richard Butte & $\mathrm{s}$ & 1 \\
\hline LM6(3) & $939 \pm 154 \mathrm{Ka}$ & $915 \mathrm{Ka}$ & R & Lava Ridge & $\mathbf{S}$ & 1 \\
\hline$N(1)$ & $1.044 \pm 0.035 \mathrm{Ma}$ & $1.06 \mathrm{Ma}$ & $\mathrm{R}$ & $\mathrm{TCH} \# 1$ & 87 & 1 \\
\hline$P(1)$ & $1.248 \pm 0.069 \mathrm{Ma}$ & $1.25 \mathrm{Ma}$ & $\mathrm{R}$ & $\mathrm{TCH}+1$ & 175 & 1 \\
\hline $\mathrm{R} 1(1)$ & $1.412 \pm 0.047 \mathrm{Ma}$ & $1.40 \mathrm{Ma}$ & $\mathbf{R}$ & TCH\#2 Piezo A & 467 & $2 U$ \\
\hline S1(1) & $1.936 \pm 0.083 \mathrm{Ma}$ & $1.45 \mathrm{Ma}$ & $\mathrm{R}$ & TCH\#1 & 523 & $2 \mathrm{~L}$ \\
\hline $\mathbf{S} 2(1)$ & $2.115 \pm 0.046 \mathrm{Ma}$ & $1.47 \mathrm{Ma}$ & $\mathrm{R}$ & TCH\#2 Piezo A & 637 & $2 \mathrm{~L}$ \\
\hline S5(1) & $2.556 \pm 0.035 \mathrm{Ma}$ & $1.54 \mathrm{Ma}$ & $\mathrm{R}$ & TCH\#2 Piezo A & 785 & $2 \mathrm{~L}$ \\
\hline$T U(1)$ & $1.865 \pm 0.024 \mathrm{Ma}$ & $>1.60 \mathrm{Ma}$ & $N$ & NPR WO-2 & 1708 & 3 \\
\hline
\end{tabular}

